IZABELA JóźWIK (Łódź)

LECh Maligranda (Luleå)

Matgorzata Terepeta (Łódź)

\title{
Stefan Kempisty (1892-1940)
}

Streszczenie. Stefan Kempisty był polskim matematykiem zajmującym się funkcjami zmiennej rzeczywistej, teorią mnogości, całkami, funkcjami przedziału i teoria pola powierzchni. W 1919 roku obronił pracę doktorską O funkcjach nawpótciaglych na Uniwersytecie Jagiellońskim w Krakowie, a jego promotorem był Kazimierz Żorawski. W grudniu 1924 roku habilitował się na Uniwersytecie Warszawskim. W latach 1920-1939 pracował na Uniwersytecie Stefana Batorego w Wilnie. Opublikował ponad czterdzieści prac naukowych i trzy podręczniki z analizy rzeczywistej oraz jedną monografię. Reprezentował w swoich pracach i na seminariach szkołę warszawską. Nazwisko Kempistego w matematyce pojawia się w związku z definicją funkcji quasi-ciągłej, różnymi ciągłościami funkcji wielu zmiennych, klasyfikacją funkcji Baire'a, Younga i Sierpińskiego, funkcjami przedziału oraz całkami Denjoy i Burkilla.

Zainteresowaliśmy się Kempistym ze względu na jego dorobek naukowy, pewne niewyjaśnione informacje osobiste oraz 125 rocznicę urodzin przypadającą w 2017 roku. Przedstawiamy więc jego biografię, udział w konferencjach, sylwetki żony Eugenii i córki Marii oraz jego dorobek naukowy. Wszystkie informacje o Kempistym pochodzą z następujących głównych źródeł: [Kf1] - [Kf4], [Kf8], [Kf9], [Kf12] - [Kf14], [Kf16], [Kf19], [Kf20], [Kf22]-[Kf25].

2010 Klasyfikacja tematyczna AMS (2010): 01A60, 01A70, 26A21, 26A75, 28B15, 28B20.

Stowa kluczowe: XX-wieczna matematyka i matematycy w Europie, badania bibliograficzne, Stefan Kempisty, całka Kempistego, funkcje quasi-ciagłe, funkcje przedziału, pole powierzchni.

1. Biografia Stefana Kempistego. Stefan Jan Kempisty urodził się 23 lipca 1892 roku w Zamościu. Jego rodzicami byli Jan Kempisty (15 grudnia 1867, Ostrowia Mazowiecka - 27 marca 1937) i Stefania Rozalia z domu Kasprzycka (1865-3 kwietnia 1932). Ich ślub odbył się 
w 1889 roku w parafii pod wezwaniem św. Barbary w Warszawie. Ojciec Stefana był kupcem i przemysłowcem, związanym z amerykańską firmą The Kempisty Company, produkującą maszyny do szycia. Właścicielem firmy był Piotr Kempisty (pochodzaccy także z Ostrowii Mazowieckiej), zaś od 1888 roku jej przedstawicielem na Polskę został brat Piotra Jan (zob. [67]). Jego córka Wanda w 1928 roku wyszła za mąż za Jana Raczyńskiego, który przejął firmę działającą do dziś (zob. [21]).

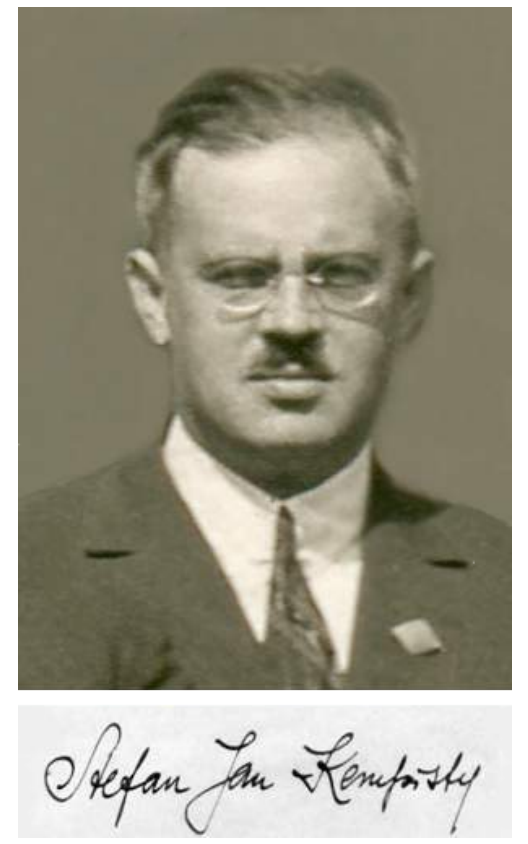

Fot. 1: Zdjęcie Kempistego z 1927 roku i jego podpis.

Ponieważ Stefan Kempisty był jedynakiem, Wanda nie była jego rodzoną siostrą. Stąd wiadomo, że Jan Kempisty - współwłaściciel firmy The Kempisty Company oraz Jan Kempisty - ojciec Stefana to dwie różne osoby. Nie znamy stopnia pokrewieństwa obu Janów, ale można przypuszczać, że były pomiędzy nimi jakieś koligacje rodzinne, ponieważ zarówno rodzice Stefana, jak i Wanda Raczyńska pochowani są w grobie rodzinnym Kempistych na Powązkach.

W 1897 roku firma The Kempisty Company została przekształcona w spółkę The Kempisty-Kasprzycki Company, której współwłaścicielem został Józef Kasprzycki ${ }^{1}$, prawdopodobnie spokrewniony z matką Stefana.

\footnotetext{
${ }^{1}$ Opis pawilonu nr 46 The Kempisty, Kasprzycki Company na Wystawie Przemysłu i Rolnictwa w Częstochowie w 1909, data dostępu 07.09.2017.
} 
Stefan uczęszczał do gimnazjum filologicznego i następnie do siedmioklasowej Szkoły Handlowej w Lublinie, z której został wydalony za udział w strajku szkolnym. Po przekształceniu tej szkoły na polską powrócił do niej i ostatecznie ukończył ją w 1909 roku. Studia wyższe odbywał początkowo w Paryżu, gdzie w ciągu dwóch lat złożył egzaminy na Wydziale Nauk Ścisłych Sorbony z trzech przedmiotów: matematyki ogólnej, fizyki ogólnej i mechaniki teoretycznej, uzyskując w 1911 roku stopień licencjata nauk ścisłych (licencié ès sciences). Podczas studiów należał do odłamu młodzieży, która wystąpiwszy z organizacji studenckiej „Spójnia”, założyła Stowarzyszenie Polskiej Młodzieży Niepodległościowej Postępowej w Paryżu „Filarecja”.

W 1912 roku rodzina Kempistego przeniosła się do Woroneża, gdzie Stefan zdał w tymże roku państwowy egzamin dojrzałości uprawniający do studiów uniwersyteckich w Rosji. W 1914 roku przed Komisją Egzaminacyjną Uniwersytetu Noworosyjskiego w Odessie uzyskał świadectwo nauczyciela gimnazjalnego, uprawniające do nauki matematyki w gimnazjach. Egzamin obejmował następujące przedmioty: wstęp do analizy, wyższej algebry, rachunku różniczkowego i całkowego, geometrii analitycznej i różniczkowej, teorii liczb, teorii prawdopodobieństwa, teorii różnic skończonych, fizyki, astronomii sferycznej i opisowej oraz meteorologii.

W latach 1915-1917 kontynuował studia matematyczne i filozoficzne na Uniwersytecie Jagiellońskim (dalej: UJ) w Krakowie. Uczyli go m.in. A. L. Birkenmajer, A. Hoborski, W. Natanson, A. Rosenblatt, J. Śleszyński, S. Zaremba i K. Żorawski².

W latach 1917-1919 uczył matematyki w prywatnych gimnazjach warszawskich i na kursach pedagogicznych dla kobiet pod kierunkiem Jana Miłkowskiego w Warszawie. Był jednym z organizatorów Związku Zawodowego Nauczycieli Szkół Średnich. W roku akademickim 1917/1918 prowadził także wykład luźny (czyli nieobowiązkowy) z Teorji liczb naturalnych na II kursie (roku) na Wydziale Fizyczno-Matematycznym Wolnej Wszechnicy Polskiej.

W 1919 roku Stefan Kempisty uzyskał stopień doktora filozofii na Wydziale Filozoficznym UJ na podstawie rozprawy O funkcjach nawpótciagłych, której promotorem był Kazimierz Żorawski³ .

${ }^{2}$ Aleksander Ludwik Birkenmajer (1890-1967), Antoni Maria Emilian Hoborski (1879-1940), Władysław Natanson (1864-1937), Alfred Rosenblatt (1880-1947), Jan Śleszyński (1854-1931), Stanisław Zaremba (1863-1942), Kazimierz Żorawski (18661953).

${ }^{3}$ Tytuł rozprawy doktorskiej bywa pisany O funkcjach półciagłych, O funkcjach nawpół ciagtych oraz $O$ funkcjach nawpót-ciaglych. Ponadto promotorem był Żo- 


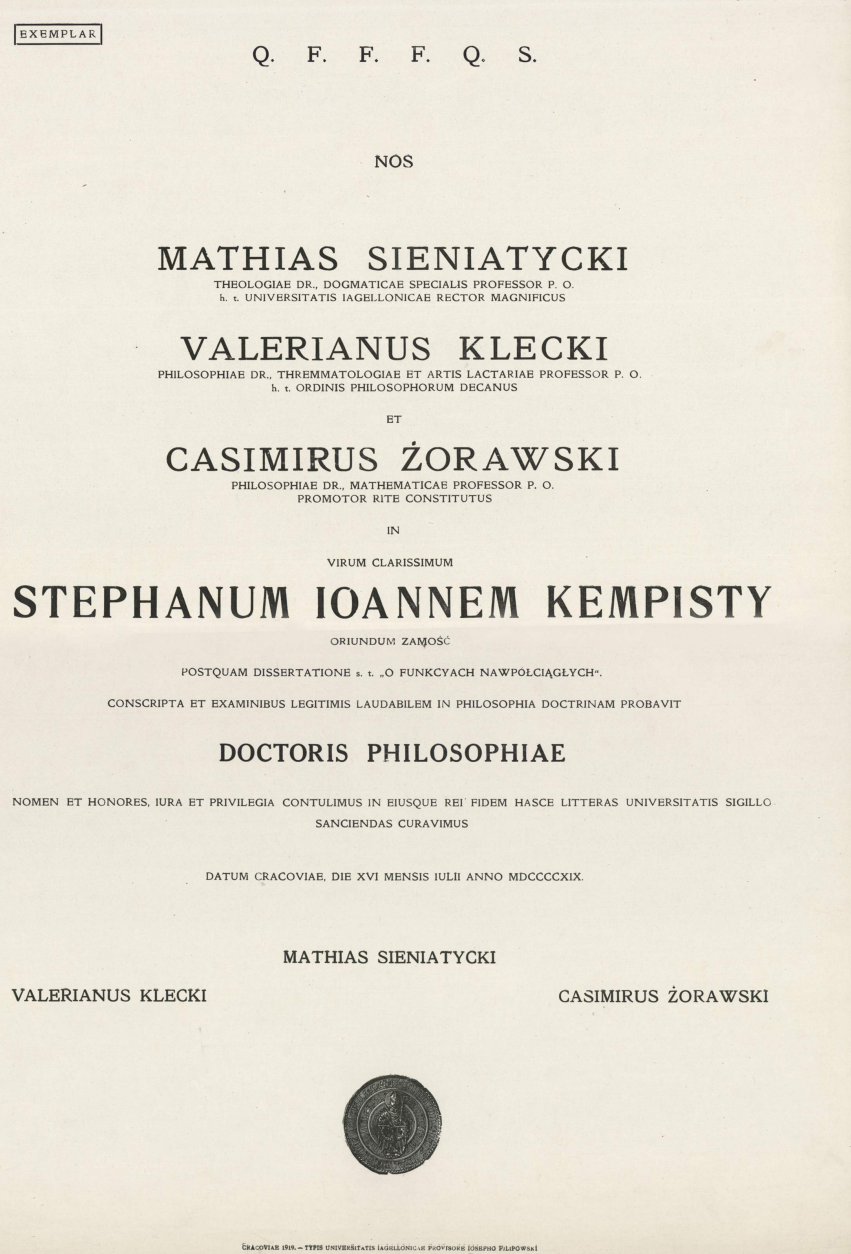

Fot. 2: Dyplom doktorski Stefana Kempistego z UJ z 1919 roku. Skan pochodzaccy z [Kf1].

Podanie z prośbą o rozpoczęcie procedury związanej z doktoratem na Wydziale Filozoficznym UJ złożył 5 lipca 1918 roku. Tutaj znajduje się jego własnoręcznie napisany życiorys z 4 lipca 1918 roku. Zachowały się protokoły egzaminów doktorskich, które zdał celująco: filozofię 11 lipca 1919 oraz matematykę i geofizykę 15 lipca 1919 (zob. [Kf1]). Ocenę pracy doktorskiej z 8 grudnia 1918 roku napisał Stanisław Zaremba i podpisał Jan Śleszyński. Promocja doktorska odbyła się 16 lipca 1919 roku.

rawski, a nie Zaremba, jak napisali Zdzisław Opial [Kf19, str. 338], Zofia Walczy [Kf24, str. 73], Stanisław Domoradzki i Zofia Pawlikowska-Brożek [Kf6, str. 130] oraz Wiesław Wójcik [Kf25, str. 181-182]. 
W roku akademickim 1919/1920 Kempisty był starszym asystentem w katedrze matematyki na Wydziale Elektrotechnicznym i Budowy Maszyn Politechniki Warszawskiej. Podczas najazdu bolszewickiego wstąpił, jako ochotnik, do I Pułku Wojsk Łączności. Po wznowieniu zajęć na Politechnice był nadal asystentem w pierwszym trymestrze roku akademickiego 1920/1921.

Dnia 1 października 1920 roku $^{4}$ został powołany na stanowisko zastępcy profesora Matematyki II na Wydziale Matematyczno-Przyrodniczym Uniwersytetu Stefana Batorego (dalej: USB) w Wilnie ${ }^{5}$. Od roku 1920 zarządzał biblioteką i administracją połączonych Seminariów Matematycznych.

Habilitował się (uzyskał vienam legendi) na Uniwersytecie Warszawskim w grudniu 1924 roku, a jego praca miała tytuł O funkcjach pochodnych ograniczonych i została wydrukowana w 1925 roku jako [K15].

W dniu 18 lutego 1925 roku ożenił się z Eugenią Pogorzelską (19001982), z którą miał córkę Marię Kempisty (1925-1989). Maria była docentem na UW i zajmowała się cybernetyką oraz logiką. Była ona pierwszą i najbardziej do dziś znaną w Polsce kobietą-cybernetykiem. O żonie i córce Kempistego napiszemy osobno w części trzeciej.

Dnia 1 października 1925 roku Kempisty został mianowany profesorem nadzwyczajnym matematyki na Wydziale Matematyczno-Przyrodniczym USB (postanowienie z 18 grudnia 1924). Hugo Steinhaus proponował na katedrę A. Rosenblatta, a dalej K. Kuratowskiego, A. Rajchmana, B. Knastera i S. Saksa ${ }^{6}$, jednak katedrę otrzymał Stefan Kempisty (zob. [Kf5, str. 226]). W latach 1928/1929 i 1929/1930 Kempisty był prodziekanem tegoż Wydziału.

W roku 1930 został przewodniczącym Komisji Sportowej Senatu Akademickiego, a po jej przekształceniu Komisji Wychowania Akademickiego, gdzie przez pięć lat pełnił obowiązki przewodniczącego. Brał udział w Komisjach: Bibliotecznej i Powszechnych Wykładów Uniwersyteckich oraz Komisjach Wydziałowych: Budżetowej, Stypendialnej i Programowej.

${ }^{4}$ W życiorysie z 1935 roku [Kf2] czytamy, że miało to miejsce 1 października 1920 roku, a w [Kf23, str. 2] widnieje data 14 maja 1920 roku. Jeszcze w [Kf4, str. 332] i [Kf23, str. 90] (sic!) znajduje się informacja, że nastąpiło to 1 grudnia 1920 roku.

${ }^{5}$ Nauki matematyczne i przyrodnicze na uniwersytetach polskich w pierwszych latach niepodległości wchodziły w skład Wydziałów Filozoficznych, a wyjątek był jedynie na USB w Wilnie, który od wznowienia w 1919 roku posiadał samodzielny Wydział Matematyczno-Przyrodniczy.

${ }^{6}$ Kazimierz Kuratowski (1896-1980), Aleksander Rajchman (1890-1940), Bronisław Knaster (1893-1980), Stanisław Saks (1897-1942). 


\section{Curriculum utae}

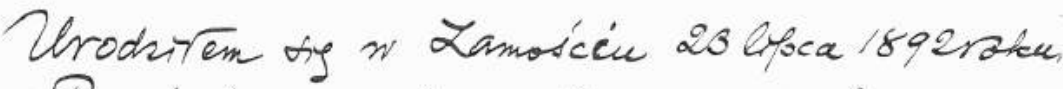

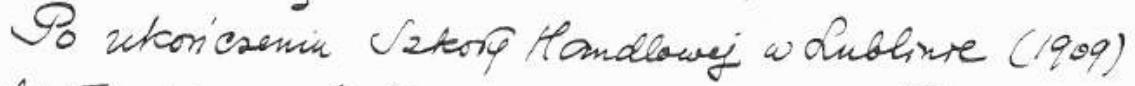
Udarem oip na tudia univerzytecteie do Paryse, gdrie otrymaran Nopten licenejata nank vispoh (III).

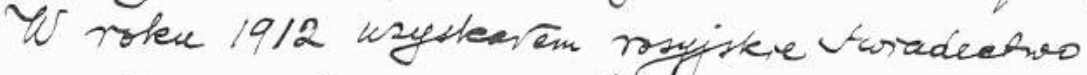
doprarosic $w$ Simnazim filologiesnem $w$ Corronesw.

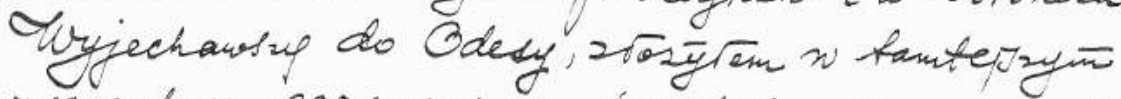

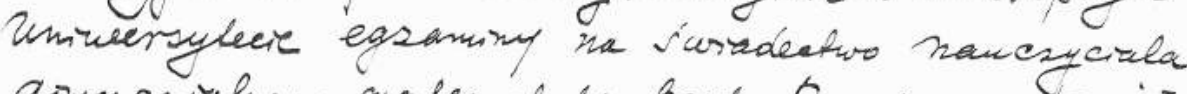
ginnaspreheys matematyki foned Panotroms Temijis egraminacying.

Tl latach '19,4-6 Aichariem uyeradow ha

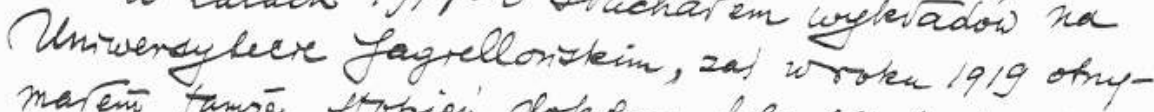
marem tanse Atopien doletora filoofi to medstabremin ropprawe p.t. "Oquntegash nawporiagrych"

Od roten 1916 do 1919 seymowaram or prakfuks

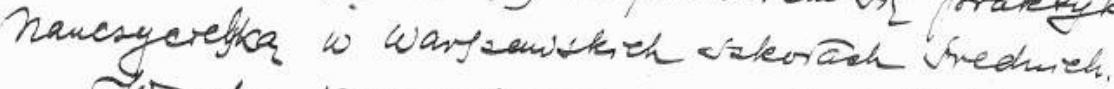

Wroten 1919 zostarem asystenten Pohfechnitei Warseawsticy w r. 1920-zastgfoca profesore. matematyti na Uniwerzytear Stefam Batorys whime.

W roke bresgeym zostarem habrltawang jako docent nowyej analizy matemakyesne na wy dark filosofismym Rniwerytefu Warlsaustrego.

uino 2quadural 1924r.

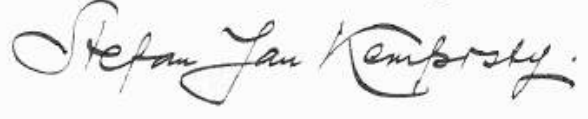

Fot. 3: Własnoręcznie napisany życiorys Stefana Kempistego z 2 grudnia 1924 roku. Skan pochodzący z [Kf2]. 
Kempisty był jednym z założycieli Wileńskiego Oddziału Polskiego Towarzystwa Matematycznego i Wydziału Matematyczno-Przyrodniczego Towarzystwa Przyjaciół Nauk w Wilnie oraz członkiem Polskiego Towarzystwa Przyrodników im. Mikołaja Kopernika. Od roku 1932 był członkiem Société Mathematique de France, a od roku 1934 również członkiem London Mathematical Society.

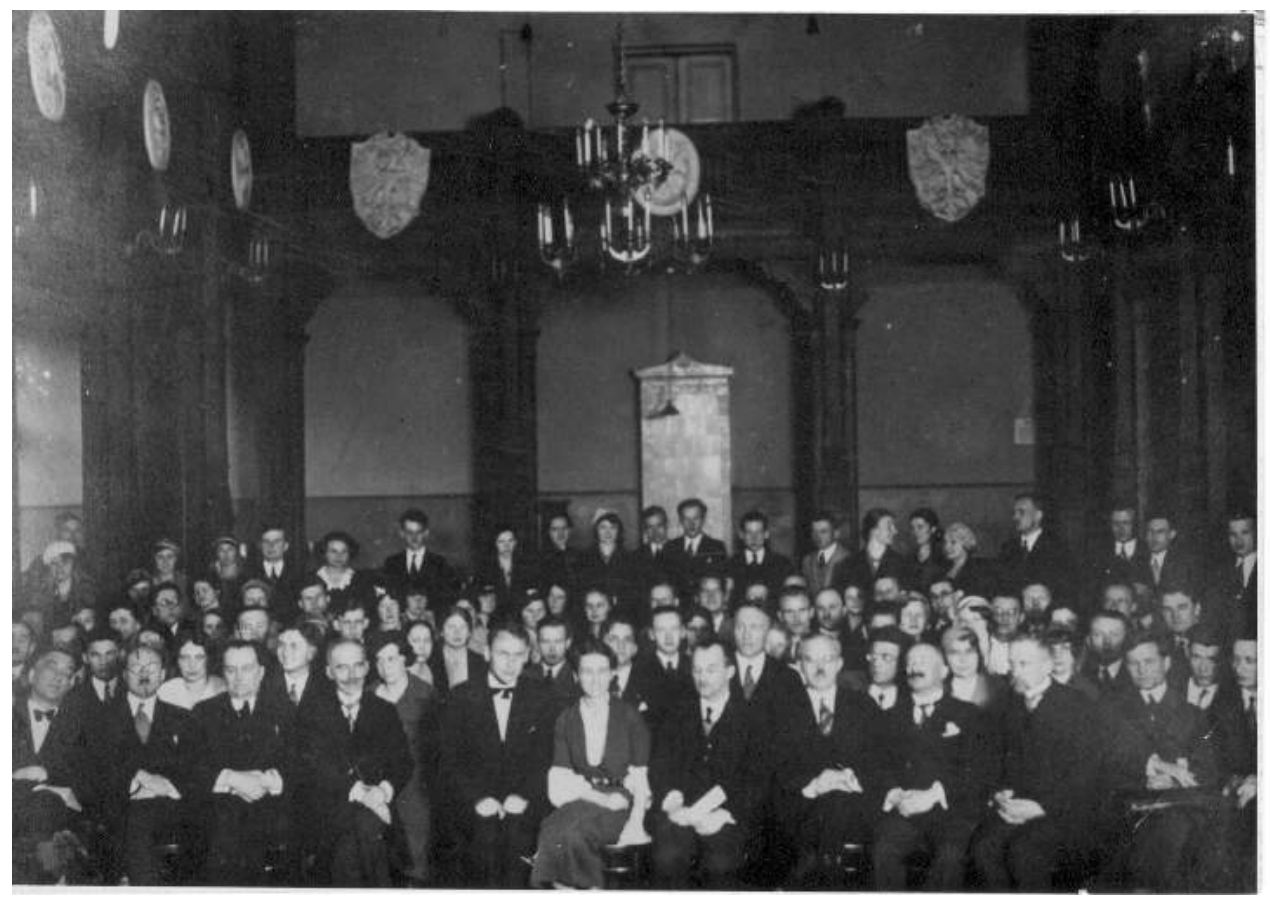

Fot. 4: XI Kongres Kół Naukowych Matematyczno-Fizycznych i Astronomicznych (25-28 maja 1933) w Wilnie. Siedzą w pierwszym rzędzie od lewej: Kazimierz Jantzen (1885-1940), Józef Stanisław Patkowski (1887-1942) - fizyk, Kazimierz Opoczyński (1877-1963) - rektor USB, Władysław Dziewulski (1878-1962) - astronom, Józef Marcinkiewicz (1910-1940), Ira Anna Koźniewska (1911-1989) - statystyk, Wacław Michał Dziewulski (1882-1938) - fizyk, Stefan Kempisty, Bogumił Jasinowski - filozof, Aleksander Januszkiewicz (1872-1955), Antoni Zygmund (1900-1992).

W 1937 roku Kempisty został profesorem zwyczajnym na USB w Wilnie. Nominacja została podpisana 14 września 1937 roku przez prezydenta Ignacego Mościckiego. Czekał więc Kempisty 12 lat na katedrę zwyczajną. W kolejnych latach akademickich, 1937/1938 oraz 1938/1939, był dziekanem Wydziału Matematyczno-Przyrodniczego USB. W kwiet- 
niu 1939 roku został wiceprezesem PTM (jednym z pięciu), a prezesem wybrano Stefana Banacha (zob. [Kf22, str. 233]).

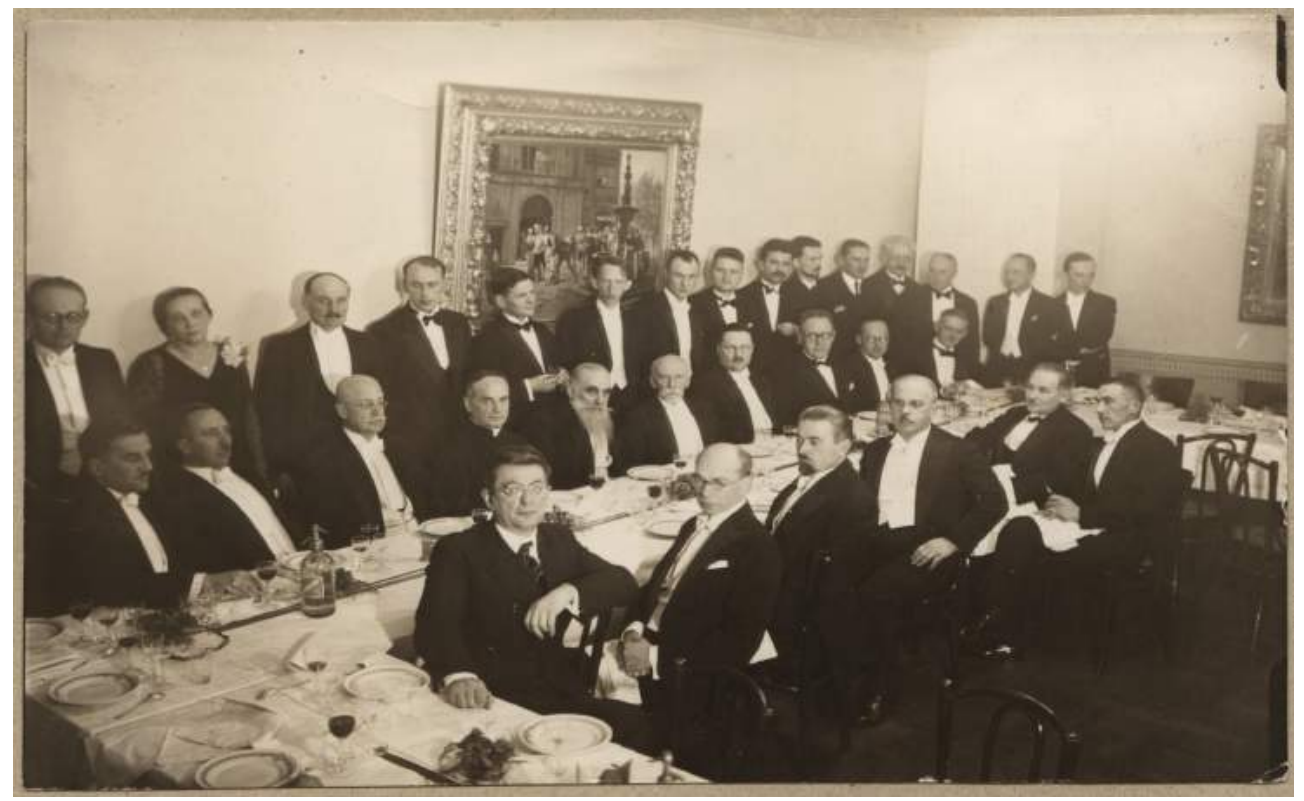

Fot. 5: Wilno, 4 marca 1936 roku. Doktorat honoris causa prof. Kazimierza Sławińskiego (1871-1941), chemika, prof. USB. Na pierwszym planie (od lewej): Juliusz Rudnicki, nn., Kornel Michejda, Stefan Kempisty, Edward Bekier. Stoją pod ścianą (czwarty i piąty od lewej): Józef Marcinkiewicz i Antoni Zygmund.

Kempisty był człowiekiem flegmatycznym, zrównoważonym, dbającym o siebie. Zajmował się sportem, narciarstwem, był nawet kuratorem wileńskiego AZS.

Na USB Kempisty wykładał: Rachunek różniczkowy i całkowy (19281931), Funkcje przedziału (1928/1929), Seminarium z teorii funkcji zmiennej rzeczywistej (1928/29), Funkcje dwóch zmiennych (1929/1930), Logiczne podstawy arytmetyki (1929/1930), Seminarium z teorii funkcji dwóch zmiennych (1929/1930), Seminarium z logicznych podstaw matematyki (1930/1931), Seminarium z zastosowań teorii mnogości do funkcji zmiennej rzeczywistej (1930/1931), Teorię mnogości (1930/1931). Ponadto prowadził Seminarium III, na którym omawiane były: funkcje zmiennej rzeczywistej, funkcje przedstawialne analitycznie, całka Lebesgue’a, funkcje przedziału, teoria mnogości i podstawy matematyki.

Nie miał talentu pedagogicznego i współpraca z młodymi, niedoświadczonymi matematykami przychodziła mu z trudem. Według stu- 
denta Leona Jeśmanowicza ${ }^{7}$, wykładał źle i był nawet „antytalentem pedagogicznym", ale jako egzaminator był wyrozumiały (zob. [Kf12, str. 313]).

Jego uczniem był tylko M. Krzyżański ${ }^{8}$, którego Kempisty wypromował na USB na doktora w 1934 roku, a którego dysertacja miała tytuł O uogólnionych funkcjach bezwzględnie ciagłych dwóch zmiennych i zawierała uogólnienie teorii Łuzina dotyczące całki Denjoy.

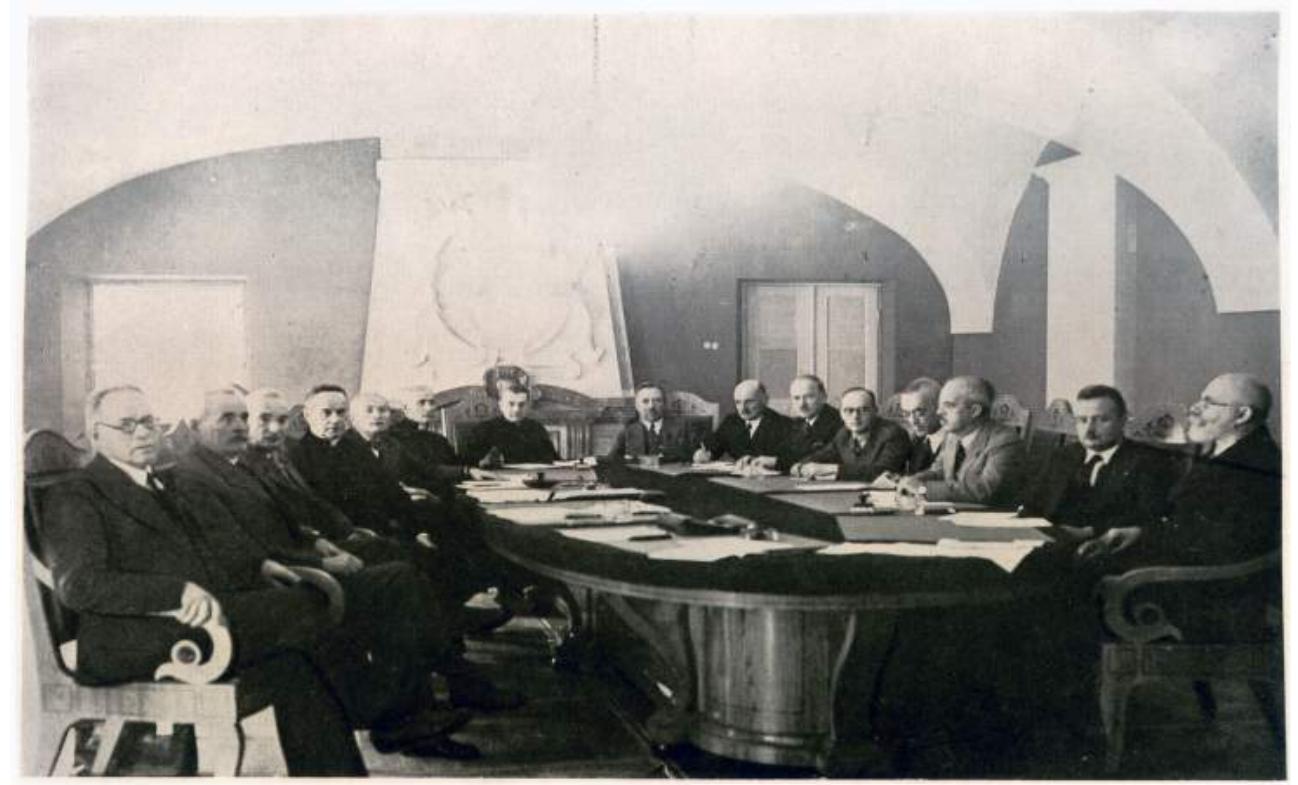

Fot. 6: Senat Uniwersytetu Stefana Batorego w Wilnie, 1938 rok. Od lewej siedzą profesorowie: Bolesław Wilanowski, Jan Oko, Stanisław Zajączkowski (prorektor), Aleksander Woycicki (rektor), Konrad Górski, Ignacy Świrski, Paweł Nowicki, Witold Cezary Staniewicz, Wacław Łastowski, Marian Morelowski, Ludomir Sleńdziński, Kazimierz Jantzen, Stefan Kempisty, Stanisław Kazimierz Hiller, Franciszek Bossowski.

Józef Marcinkiewicz wysoko cenił Kempistego i dużo mu zawdzięczał. Jedyna rzecz, która dobrze opanowałem - wielokrotnie powtarzał [Marcinkiewicz] - to teoria funkcji zmiennej rzeczywistej (zob. [Kf12, str. 313]). Przypomnijmy, że na egzaminie doktorskim Marcinkiewicza (7 czerwca 1935 roku) Kempisty zadał mu następujące pytania (zob.

${ }^{7}$ Leon Jeśmanowicz (1914-1989), polski matematyk, w latach 1938-1939 student USB, od roku 1946 pracownik naukowy UMK w Toruniu, znany karykaturzysta.

${ }^{8}$ Mirosław Godzimir Krzyżański (31 X 1907-1 XII 1965), polski matematyk, od 1949 roku profesor Uniwersytetu Jagiellońskiego i Instytutu Matematycznego PAN. 
[Kf17, str. 138]): całka Perrona i jej różne definicje, podobne pytanie dla funkcji dwóch zmiennych, powierzchnia i jej mierzenie, rezultaty Radó $i$ Tonelliego, a na habilitacji Marcinkiewicza (11 czerwca 1937 roku) zapytał go o uogólnienia koncepcji całki (zob. [Kf17, str. 142]).

19 września 1939 roku Wilno zajęły wojska sowieckie i 26 października 1939 roku Sowieci przekazali miasto Litwinom. Litwini odmówili Kempistemu prawa stałego pobytu i prawa do pracy. Kempisty był osobą zaangażowaną społecznie, o czym wspomina Jeśmanowicz (zob. [Kf12, str. 314]):

(...) w 1940 r. stał na czele Komitetu Pomocy dla byłych pracowników wileńskiego uniwersytetu. Komitet ten, zasilany przez fundusz Polskiego Czerwonego Krzyża, prowadził stołówkę, zaopatrywał w obuwie i odzież i nawet udzielał zasiłków pieniężnych.

15 czerwca 1940 roku Sowieci ponownie zajęli Wilno. Kempisty został aresztowany przez Litwinów w nocy z 11 na 12 lipca 1940 roku i osadzony $\mathrm{w}$ wileńskim więzieniu na Łukiszkach. Była to szersza akcja aresztowań, związana z „wyborami” do Sejmu Ludowego. Organ ten miał legalizować aneksję Litwy poprzez proklamowanie Litewskiej SSR i zwrócenie się do Rady Najwyższej ZSRR z prośbą o wcielenie nowej Republiki w skład ZSRR. Celem akcji było wyeliminowanie destrukcyjnego, antypaństwowego elementu, agitujacego przeciw ludowemu rzadowi $i$ zakłócajacego porzadek wyborczy, w tym m.in. wysokich polskich urzędników, oficerów i polityków (zob. książka [Kf14, str. 64]). Kempisty był przesłuchiwany najpierw przez Litwinów, a po 20 lipca 1940 roku przez Sowietów.

Kempisty nie mógł znieść warunków panujących w więzieniu i popełnił samobójstwo, wieszając się na ręczniku w celi. Do tej pory problemem było poprawne ustalenie dnia jego śmierci. W jednych pracach podawana jest data 3 sierpnia 1940 roku (zob. [Kf14, str. 110], [Kf22, str. 386]), w innych, że 5 sierpnia 1940 roku (zob. [Kf9, str. 208], [Kf12, str. 314], [Kf16, str. 100], [Kf17, str. 135]). Dzięki informacjom i dokumentom przedstawionym w najnowszej pracy Romana Dudy (zob. [Kf10]) wiemy, że poprawna jest data 3 sierpnia 1940 roku.

Kempisty mieszkał w Krakowie, Warszawie i Wilnie pod następującymi adresami: 1918: Kraków, Al. Krasińskiego 13; 1919: Warszawa, ul. Marszałkowska 41 m. 6; 1927: Wilno, ul. Zamkowa 24 m. 5; od 1937: Wilno, ul. Zamkowa 11 i Wilno, ul. Teatralna 2a m. 4.

Grób rodziny Kempistych znajduje się na Starych Powązkach w Warszawie. Tam są pochowani rodzice Stefana Kempistego. Isnieje też sym- 

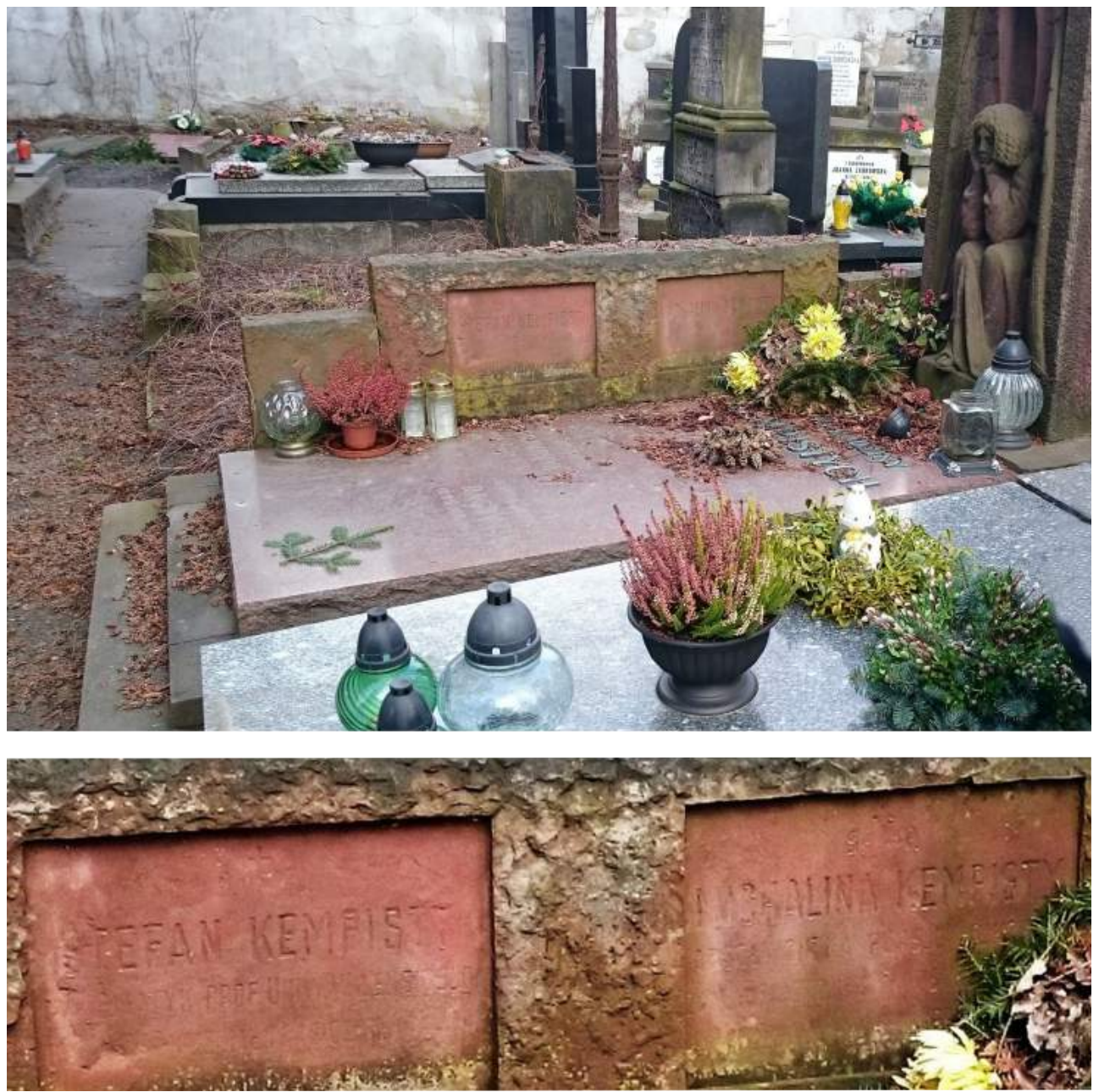

Fot. 7: Grób rodziny Kempistych i symboliczny grób Stefana Kempistego.

boliczny grób Stefana pod adresem:

http://mojecmentarze.blogspot.se/2012/08/stefania-kempisty.html (data dostępu 07.09.2017).

$\mathrm{Na}$ jego symbolicznym grobie jest napisane (napis na bocznej płycie po lewej stronie grobu):

Ś.P. STEFAN KEMPISTY. MATEMATYK PROF. UNIW. WILEŃSKIEGO. UR (...). ZGINĄE TRAGICZNIE (...). SPOCZYWA W NIEZNANEJ MOGILE

a informacja o osobach tam pochowanych znajduje się pod adresem: 
https://cmentarze.um.warszawa.pl/pomnik.aspx?pom_id=18783 (data dostępu 07.09.2017).

\section{Pomniki - szczegóły}

\begin{tabular}{|c|c|c|c|c|c|c|c|c|}
\hline \multicolumn{2}{|l|}{ Lokalizacja } & \multicolumn{7}{|c|}{ Cmentarz Stare Powązi } \\
\hline \multicolumn{2}{|c|}{ Imię i nazwisko } & \multicolumn{7}{|c|}{ KEMPISTYCHOWIE } \\
\hline \multicolumn{9}{|l|}{ Pochowani: } \\
\hline Imię & Nazwisko & Data & dze & enia & Data & $5 \mathrm{mi}$ & ierci & Uwagi \\
\hline STEFANIA & KEMPISTOWA & & & & 1932 & 4 & 3 & \\
\hline JANINA & STRAUSOWA & 1890 & & & 1978 & & & \\
\hline JAN & KEMPISTY & & & & 1937 & 3 & 27 & \\
\hline WANDA & RACZYŃSKA & 1903 & 9 & 8 & 1984 & 7 & 6 & \\
\hline MICHALINA & KEMPISTY & & & & 1917 & & & POCHÓWEK SYMBOLICZNY \\
\hline STEFAN & KEMPISTY & & & & & & & DATY NIECZYTELNE POCHÓWEK SYMBOLICZNY \\
\hline
\end{tabular}

Fot. 8: Szczegóły dotyczące pomnika rodziny Kempistych na Starych Powązkach.

\section{Udział Kempistego w konferencjach i jego wyjazdy na-} ukowe. Stefan Kempisty brał aktywny udział w konferencjach oraz często przebywał za granicą. Wymieńmy chronologicznie konferencje, na jakich Kempisty był obecny:

1927 - I Polski Zjazd Matematyczny (Lwów 7-10 IX 1927), gdzie był z żoną Eugenią oraz wygłosił dwa odczyty: O całkach funkcji przedziału, choć wcześniej zgłosił komunikat Całka aproksymatywna, oraz O pochodnych funkcji przedziatu zamiast komunikatu Catkowanie pochodnej regularnej. Odczyty te zostały opublikowane w języku francuskim w [K20] i [K21]. Załączamy zdjęcie uczestników Zjazdu zrobione przed Politechniką Lwowską, na którym widzimy wielu znanych matematyków oraz jest też widoczny Kempisty (fot. 9).

1928 - VIII Międzynarodowy Kongres Matematyków (ICM) w Bolonii (3-10 IX 1928), gdzie był z żoną. W Kongresie uczestniczyło ponad 30 matematyków polskich, w tym wielu z żonami jako osobami towarzyszącymi (L. Chwistek, A. Hoborski, F. Leja, L. Lichtenstein, S. Mandelbrojt, J. Spława-Neyman, A. Zygmund). Otton Marcin Nikodym był też z żoną Stanisławą, ale ona była jednym z uczestników Kongresu i wygłosiła odczyt Sur une propriété topologique du plan euclidien. 


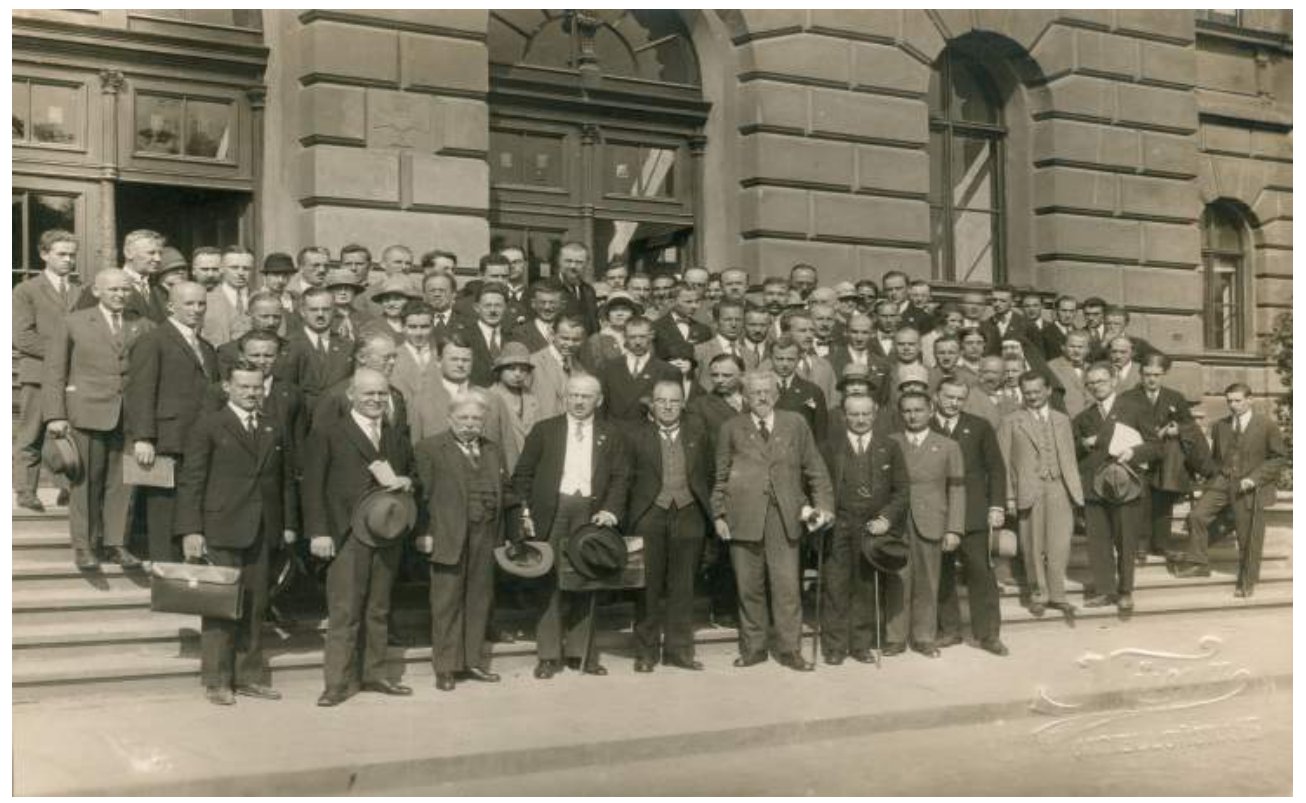

Fot. 9: Uczestnicy Pierwszego Polskiego Zjazdu Matematycznego we Lwowie w 1927 roku. Kempisty stoi w trzecim rzędzie trzeci od lewej.

1929 - I Kongres Matematyków Krajów Słowiańskich (Warszawa 23-27 IX 1929), gdzie był z żoną oraz wygłosił dwa odczyty: Całkowanie $w$ przedziale nieskończonym i Sur les fonctions ponctuellement discontinues. Odczyty te zostały opublikowane w języku francuskim w [K24] i [K25]. Istnieje zdjęcie uczestników Kongresu zrobione przed Politechniką Warszawską (fot. 10).

1931 - II Zjazd Matematyków Polskich (Wilno 23-26 IX 1931), na którym Kempisty był sekretarzem generalnym, a w Sekcji II wygłosił odczyt: O funkcjach kwaziciagłych. Załączamy zdjęcie uczestników Zjazdu (fot. 12).

1932 - II Kongres Matematyków Rumuńskich (Turnu-Severin 5-9 V 1932), gdzie wygłosił odczyt Sur les fonctions partiellement continues, który został opublikowany jako [K32]. Na tym Kongresie był z żoną. Oprócz niego z żonami z Polski byli jeszcze A. Rosenblatt i A. Zygmund. Ponownie O. M. Nikodym był też z żoną Stanisławą, która była regularnym uczestnikiem Kongresu i wygłosiła odczyt Sur une propriété topologique du plan. 


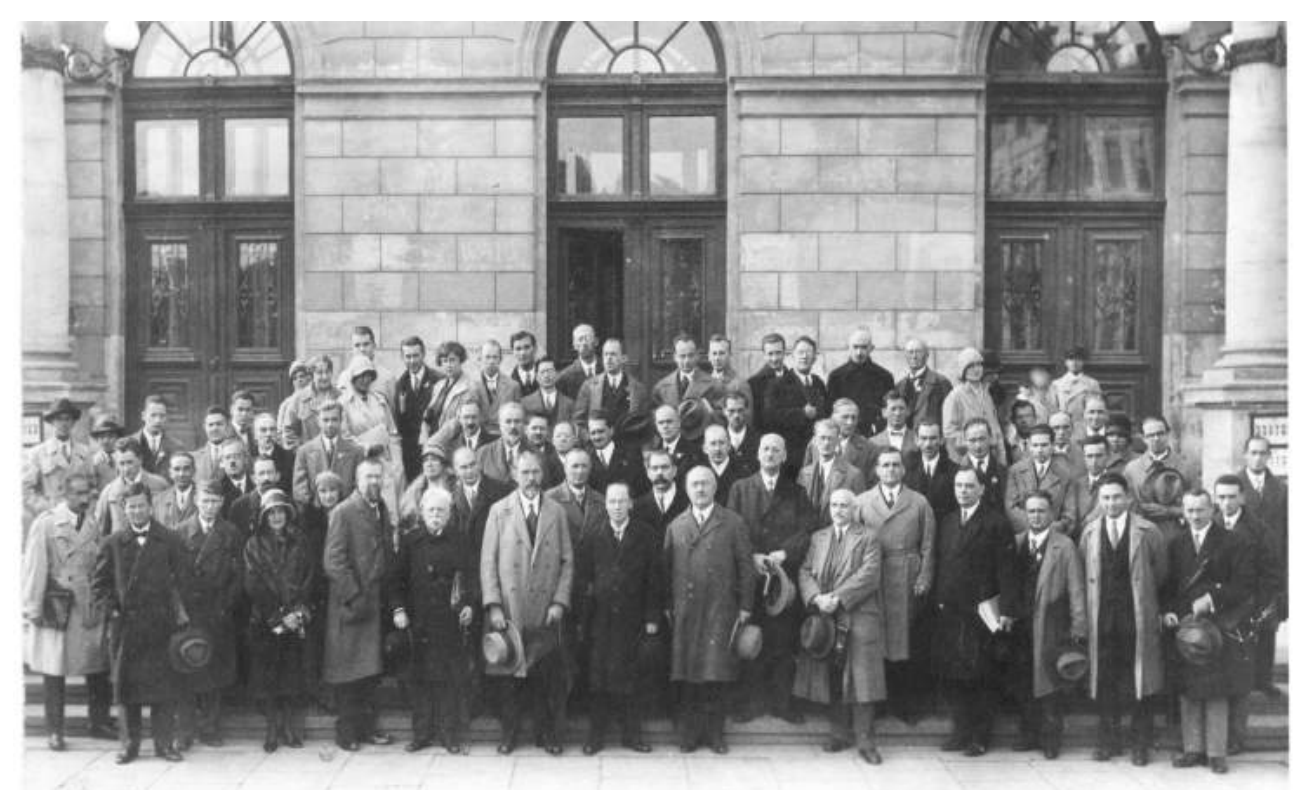

Fot. 10: Uczestnicy I Kongresu Matematyków Krajów Słowiańskich w Warszawie w 1929 roku. Kempisty stoi w drugim rzędzie czwarty od lewej.

1932 - IX Międzynarodowy Kongres Matematyków (ICM) w Zurichu (4-12 IX 1932), na którym było obecnych 30 matematyków polskich oraz żony S. Saksa i A. Zygmunda.

1937 - III Zjazd Matematyków Polskich (Warszawa 28 IX-3 X 1937), na którym Kempisty został wybrany do Prezydium Zjazdu. Zjazd był połączony z jubileuszem 65-lecia działalności naukowej, pedagogicznej i społecznej Samuela Dicksteina ${ }^{9}$, a Akademia jemu poświęcona odbyła się w ostatnim dniu Zjazdu. Wydana została tėz Księga Pamiątkowa Jubileuszu [36], zawierająca wiele interesujących szczegółów z jego działalności. Wśród wielu przedmówców był też Stefan Kempisty, jako profesor i dziekan Wydziału Matematyczno-Przyrodniczego Uniwersytetu Stefana Batorego w Wilnie, który stwierdził (zob. [36, str. 18], cytujemy jego tekst w oryginale):

${ }^{9}$ Samuel Dickstein (12 V 1851 Warszawa - 28 IX 1939 Warszawa), polski matematyk, pedagog i historyk nauki. Profesor Uniwersytetu Warszawskiego i założyciel oraz wydawca czasopism „Wiadomości Matematyczne” oraz „Prace MatematycznoFizyczne". 


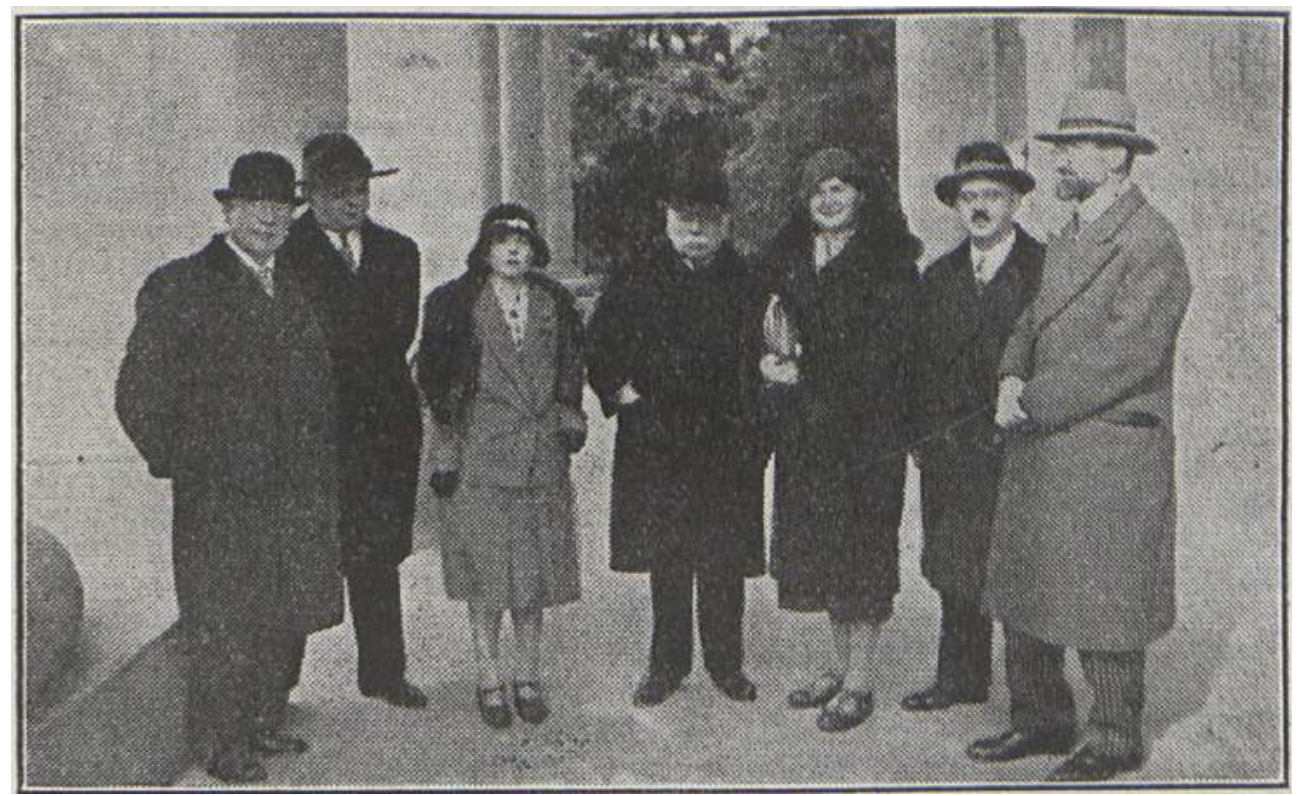

Fot. 11: II Polski Zjazd Matematyczny w Wilnie w 1931 roku. Stoją od lewej: Wacław Sierpiński, Petre Sergescu, Maria Kasterska-Sergescu, Samuel Dickstein, Thérèse-Marie Denjoy, Stefan Kempisty i Arnaud Denjoy. Skan pochodzi z [Kf7].

Gdy podziwiamy wspaniały rozwój matematyki polskiej od czasu odzyskania niepodległości i szukamy przyczyn tego zjawiska, pamiętamy zawsze, że zarówno w smutnych czasach niewoli jak w groźnych chwilach wojny kult i zamiłowanie do matematyki szerzył i podtrzymywał dzisiejszy Jubilat, wówczas generalny matematyczny redaktor, wydawca, autor, tłumacz, recenzent, bibljograf i popularyzator w jednej osobie.

Gdy nauczamy, zdajemy sobie sprawę, że obok nazw matematycznych wybranych przez Jana Śniadeckiego i Hoene-Wrońskiego używamy wielu terminów utworzonych przez Profesora Dicksteina w czasie przyswajania polskiej literaturze matematycznej dzieł obcych. (...)

Gdy więc dziś przypadł mi w udziale zaszczyt reprezentowania Uniwersytetu Stefana Batorego i Wileńskiego Towarzystwa Przyjaciół Nauk, składam jaknajszczersze i jaknajlepsze życzenia Czcigodnemu Jubilatowi i przyłączam się do powszechnego hołdu polskich ośrodków naukowych. 


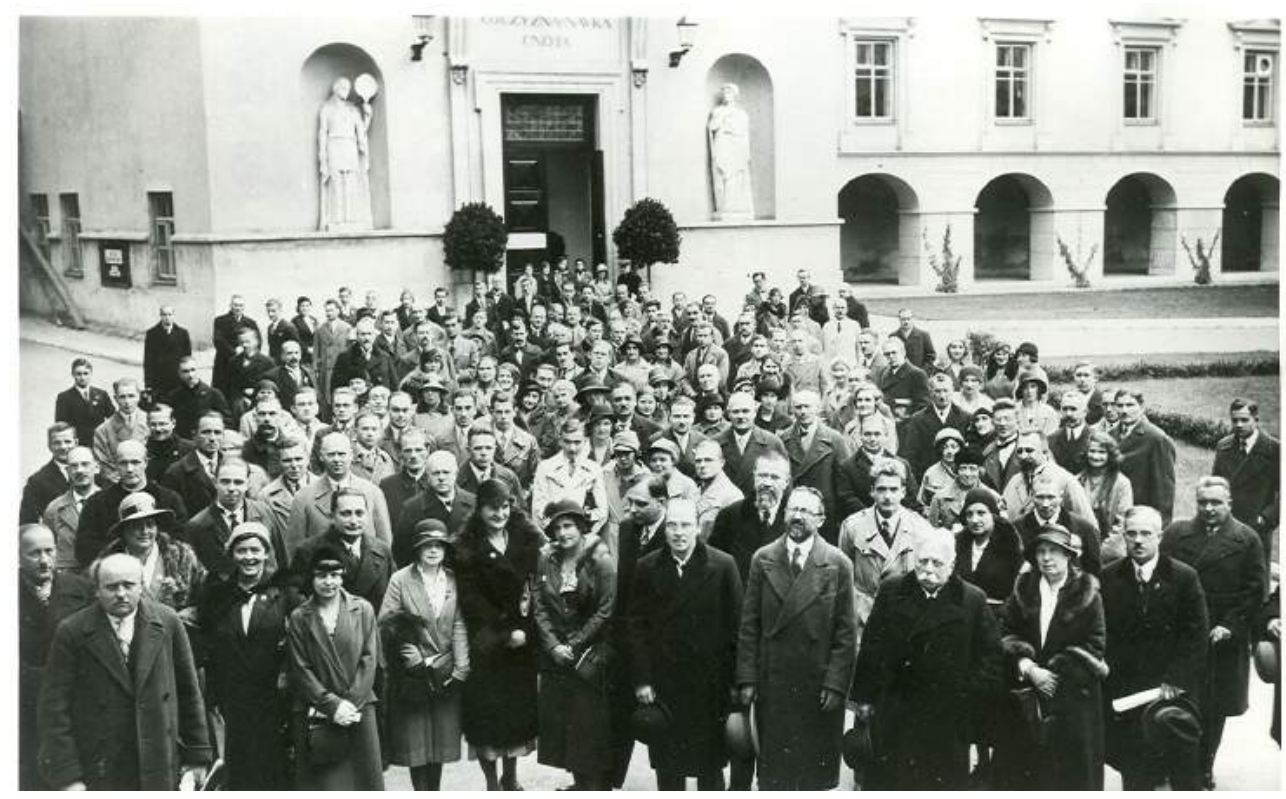

Fot. 12: Uczestnicy II Polskiego Zjazdu Matematycznego w Wilnie w 1931 roku. Kempisty stoi w pierwszym rzędzie pierwszy od prawej (obok prawdopodobnie żona Eugenia).

Pobyty Kempistego za granica wymieniamy chronologicznie:

1927 - Sorbona - trzymiesięczny pobyt naukowy z funduszu MWRiOP (zob. [Kf22, str. 178]).

1934, jesień i 1935, jesień (pół roku), 1936 - Paryż. Współpracował z J. Hadamardem, G. Julią, A. Denjoy ${ }^{10}$, wygłaszał też wykłady (zob. [Kf22, str. 178]).

1 IX 1935-20 IV 1936 - dwa trymestry w Paryżu i trzy miesiące w angielskim Cambridge. Z funduszy MWRiOP otrzymał $2500 \mathrm{zł}$ (prosił o $5000 \mathrm{zł})$.

W sprawozdaniu [Kf3] z kwietnia 1936 roku czytamy, że w listopadzie i grudniu 1935 roku Stefan Kempisty brał udział w Seminarium Hadamarda w Collége de France z referatem O catce Denjoy funkcji wielu zmiennych, streszczenie którego zostało opublikowane w [K36], w wykładach Borela i Darmois ${ }^{11}$ z teorii prawdopodobieństwa.

${ }^{10}$ Jacques Hadamard (1865-1963), Gaston Julia (1893-1978), Arnaud Denjoy (1884-1974).

${ }^{11}$ Émile Borel (1871-1956), Georges Darmois (1893-1978), matematyk i statystyk francuski, który jako pierwszy matematyk francuski uczył i popularyzował angielską statystykę matematyczną. 
Brał udział w Seminarium z topologii w Instytucie Poincarégo, prowadzonym przez prof. Julię. Uczestniczył też w wykładach specjalnych Denjoy, Montela, Frecheta i Julii ${ }^{12}$. Referował pracę o wyznaczaniu pola powierzchni w $\mathbb{R}^{3}$ za pomocą wielościanów wpisanych [K38].

4 i 5 marca 1936 roku prowadził, w obecności Denjoy, Montela i Darmois, wykłady o nieaddytywnych funkcjach przedziału. Na propozycję Denjoy opracował te wykłady w formie książkowej i wydał jako monografię $\left[K_{s} 4\right]$.

3. Żona i córka Stefana Kempistego. W dniu 18 lutego 1925 roku w Parafii św. Jana w Warszawie odbył się ślub Stefana Kemistego z Eugenią (Eugenją) Pogorzelską (7/20 XII 1900 Warszawa - 30 XII 1982 Warszawa). Była ona magistrem biologii, nauczycielką w Prywatnym Żeńskim Gimnazjum i Liceum Anny Jakubowskiej w Warszawie oraz pracownikiem Państwowego Urzędu Repatriacyjnego (zob. [Kf18]). Wiele informacji na temat prywatnego życia Kempistych można znaleźć w [Kf11] oraz [Kf26]. Np. w [Kf11, str. 66] czytamy, iż Kempisty błagat kolegów, ażeby go wybrali dziekanem dlatego, że mu brakowało pieniędzy na pokrycie kosztów rozrzutnej żony. Natomiast w [Kf26, str. 671] pojawiły się informacje o tym, że żona Kempistego zdradzała go z jakimś generałem. Wtedy

Kempisty żądał od rycerza ożenku z żoną. Generał odmówił $(\ldots)$. Byli wyznaczeni sekundanci, ze strony Kempistego Singalewicz, który mi o tym opowiadał. Kempisty pojedynku nie przyjmował, żądał „odszkodowania”.

Po śmierci Kempistego, w sierpniu 1940 roku, Eugenia wyszła, w czasie wojny, ponownie za mąż - za fizyka Szczepana Szczeniowskiego ${ }^{13}$. Do tego momentu Szczeniowski był starym kawalerem. Ponieważ wypis aktu urodzenia Eugenii Pogorzelskiej (nr 103/1901), zawierający dokładną datę ślubu ze Stefanem Kempistym, został dokonany 29 lipca 1941 roku, prawdopodobnie ślub ze Szczepanem Szczeniowskim miał miejsce w 1941 roku w Warszawie. Eugenia zmieniła nazwisko z Kempisty na Szczeniowska.

Stefan i Eugenia Kempistowie mieli jedną córkę Marię Kempisty (15 XI 1925 Warszawa - 9 XII 1989 Warszawa).

\footnotetext{
${ }^{12}$ Maurice Fréchet (1878-1973), Paul Montel (1876-1975).

${ }^{13}$ Szczepan Szczeniowski (26 XII 1898 Warszawa-18 II 1979 Warszawa), polski fizyk, profesor na UJK we Lwowie (1930-1936), na USB w Wilnie (1937-1939) i na Politechnice Warszawskiej (1957-1979), poseł na Sejm PRL I kadencji, autor wielotomowego podręcznika Fizyka doświadczalna (zob. [Kf21]).
} 
Maria zrobiła maturę w lipcu 1943 roku na tajnych kompletach w liceum matematyczno-fizycznym im. N. Żmichowskiej i we wrześniu 1945 roku rozpoczęła studia na Akademii Handlowej w Poznaniu. Pod koniec 1948 roku wyszła za mąż za Waldemara Goettiga (?-16 XI 1989) - studenta Akademii Handlowej. Pracowała w PZU, Dyrekcji Przemysłu Miejscowego w Poznaniu jako główny księgowy Zakładu Metalowego MT-2. W 1954 roku przeniosła się wraz z mężem i synem do Warszawy i od 1957 roku pracowała w Wydziale Inwestycji PAN.

W 1950 roku urodziła syna Stefana Jana Goettiga, który później został fizykiem i pracował w Instytucie Fizyki Teoretycznej na Wydziale Fizyki UW (zm. 26 I 2005). Na urlopie macierzyńskim napisała pracę magisterską Organizacja przemystu terenowego w Polsce Ludowej i 23 czerwca 1958 roku otrzymała dyplom magistra nauk ekonomiczno-handlowych Wyższej Szkoły Ekonomicznej w Poznaniu nr 191/511.

Po rozwodzie wróciła do nazwiska panieńskiego, chcąc kontynuować tradycje naukowe ojca Stefana, i przy tym nazwisku pozostała, wychodząc po raz drugi za mąż za Krzysztofa Tormanowskiego (?-15 XII 2010).

W 1958 roku prof. Henryk Greniewski (1903-1972), przewodniczący Komisji Ekonometrycznej PAN, zatrudnił Marię jako asystenta w Zakładzie Cybernetyki Instytutu Filozofii i Socjologii PAN. Od 1 marca 1963 roku do 30 września 1972 roku Maria pracowała na UW, najpierw na Wydziale Ekonomii Politycznej w Katedrze Ekonometrii jako starszy asystent (od 1 III 1963), adiunkt (od 1 X 1965) i docent nauk humanistycznych w zakresie logiki i cybernetyki (od 2 XI 1968). 1 stycznia 1969 roku została przeniesiona do Instytutu Filozofii Wydziału Nauk Społecznych UW. Pracowała też w Zakładzie Elektronicznej Techniki Obliczeniowej w Warszawie. Na II Plenerze w Osiekach (26 VIII-15 IX 1964) wygłosiła wykład Cybernetyka a sztuka.

Wcześniej, tzn. 4 XII 1962 roku, Maria obroniła na Wydziale Filozoficznym UW pracę doktorską Binarne sprzężenia zwrotne, opublikowaną w „Studia Logica” [38]. Promotorem był Henryk Greniewski. Rozprawa habilitacyjna Cybernetyczny model pamięci skojarzeniowej $i$ jego zastosowania w zarzadzaniu była oceniana przez Henryka Greniewskiego, Antoniego Kilińskiego, Klemensa Szaniawskiego i Tadeusza Tomaszewskiego, a kolokwium habilitacyjne na Wydziale Filozoficznym UW odbyło się 11 kwietnia 1966 roku. 2 listopada 1968 roku zatwierdzono uchwałę Rady Wydziału Filozoficznego o nadaniu Marii stopnia naukowego docenta nauk humanistycznych w zakresie logiki (cybernetyki). 

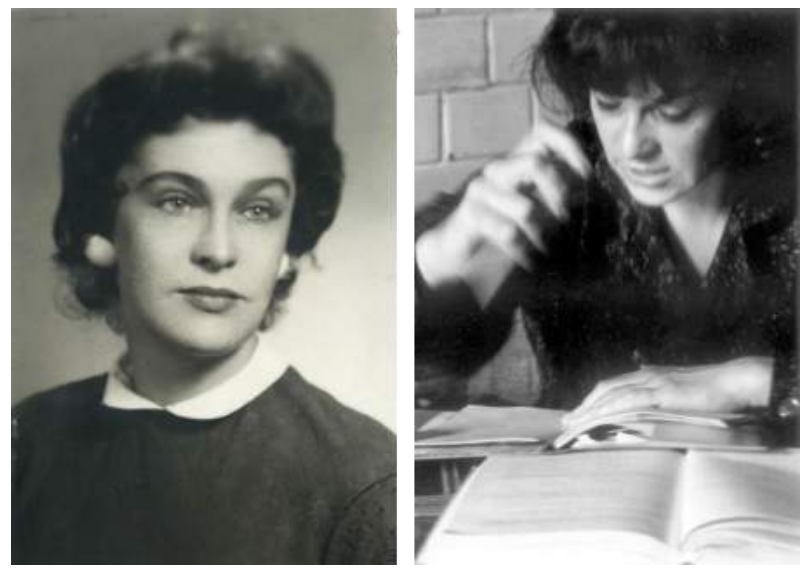

Fot. 13: Zdjęcie córki Kempistego. Po lewej zdjęcie Marii w dyplomie magisterskim (skan z [Kf15]), po prawej: Maria cybernetyk, Warszawa, 1964 (zdjęcie Danuty Rago z http://fototapeta.art.pl/fti-inv16dr.html, data dostępu 07.09.2017).

Od 1 października 1972 roku do emerytury rozpoczętej w 1985 roku Maria pracowała w Instytucie Organizacji Przemysłu Maszynowego, gdzie w październiku 1984 roku obchodzono uroczyście jej jubileusz 35lecia pracy.

Maria była członkiem Prezydium Polskiego Towarzystwa Cebernetycznego (PTC) od czasu jego powstania w 1962 roku z inicjatywy Henryka Greniewskiego. Towarzystwo liczyło około 800 członków, głównie pracowników naukowych.

Oprócz prowadzenia wykładów na UW, dużo publikowała na temat cybernetyki, jak np. książki [28], [39], [40], [42], [43] i prace [37], [41]. Była też członkiem trzech Komitetów Redakcyjnych: PWN, seria „Informacja i Sterowanie", Biuletynu Informacyjnego PTC i Małego Słownika Cybernetycznego, Wiedza Powszechna [43].

Wiemy z informacji w: https://cmentarze.um.warszawa.pl/pomnik.aspx?pom_id=27841 (data dostępu 07.09.2017), że Maria, jej matka Eugenia i ojczym Szczepan są pochowani we wspólnym grobie Pogorzelskich na Starych Powązkach w Warszawie.

4. Dorobek naukowy Stefana Kempistego. Stefan Kempisty opublikował jedną monografię [Ks4], skrypt litograficzny Rachunek ró́̇niczkowy $i$ catkowy w trzech częściach [Ks1] - [Ks3] oraz 42 prace naukowe w językach: polskim (8 prac), angielskim (1 praca) i francuskim 
(33 prace).

Monografia [Ks4] dotyczy nieaddytywnych funkcji przedziału i, jak pisaliśmy wcześniej, została wydana po wykładach Kempistego w Paryżu w marcu 1936 roku. W niej to Kempisty rozwija ideę Burkilla o całce nieaddytywnej funkcji przedziału i stosuje do dyskusji na temat obszarów i długości, a także zajmuje się całką Denjoy funkcji wielu zmiennych.

\section{Wydaroniciva Kola Malemai -Fixycznego Studentow Uniuversylelu Slefana Batenego w Wile \\ RACHUNEK \\ ROĖNICZKOWY \\ I CALKOWY}

Wykłady Prof. Dra Słefana Kempistego

Część 1 .

Liczby rzeczywiste. Ciøø̧i i szere фi.

Funkcje.

\section{Wilno 1931.}

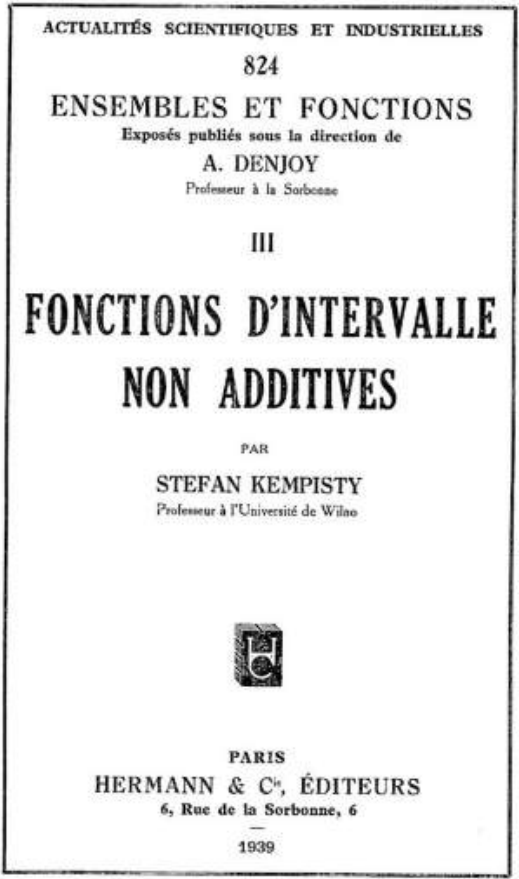

Fot. 14: Skan stron tytułowych skryptu Kempistego 1939 roku i monografii z 1931 roku.

Kempisty publikował swoje prace głównie w „Comptes Rendus Hebdomadaires des Seances de l'Académie des Sciences” (10 prac), „Fundamenta Mathematicae" (9 prac), "Annales de la Société Polonaise de Mathématique” (6 prac), „Bulletin de la Société Mathematique de France” (3 prace), ale również w czasopismach „Wektor” (3 prace) i „Wiadomości Matematyczne” (1 praca).

Zajmował się przede wszystkim funkcjami zmiennej rzeczywistej, teorią całki, teorią mnogości i podstawami matematyki. Badał różne rodzaje ciągłości, funkcje przedstawialne analitycznie, klasyfikacje Baire'a, Younga i Sierpińskiego oraz całki Denjoy i Burkilla. Nazwisko 
Kempistego w matematyce najczęściej pojawia się w związku z definicją funkcji quasi-ciągłej, klasyfikacją funkcji Baire'a, Younga i Sierpińskiego oraz całką Denjoy. Topologia znajdowała się poza głównym nurtem zainteresowań Kempistego, ale w jego dorobku pojawia się jedna praca związana z tą dziedziną. Jest to praca [K33], która dotyczy operacji na przestrzeni topologicznej i była prawdopodobnie inspirowana twierdzeniem Kuratowskiego (1920) o 14 zbiorach, mówiącym, że gdy w przestrzeni topologicznej $E$ używać naprzemiennie operacji domknięcia i dopełnienia zbioru, to otrzymamy maksymalnie 14 różnych zbiorów (nawet dla $E=\mathbb{R}$ ).

W [K33] Kempisty rozpoczął badanie własności różnych operacji określonych na podzbiorach $A$ fundamentalnego zbioru $E$, przy czym jako operację w $E$ rozumiał taką funkcję $\Phi$, która z każdym podzbiorem $A$ zbioru $E$ jednoznacznie wiązała zbiór $\Phi(A)$ będący podzbiorem zbioru $E$. Badania Kempistego obejmowały wiele różnych teorii topologicznych i były związane z tzw. operatorami sprzężonymi. Mówimy, że dwie operacje $\Phi, \Psi$ są sprzę̇̇one, jeżeli

$$
\Phi(E-A)+\Psi(A)=E \text { oraz } \Phi(E-A) \cdot \Psi(A)=0 .
$$

Przy obecnych oznaczeniach powyższy wzór ma postać:

$$
\Phi(E \backslash A) \cup \Psi(A)=E \text { oraz } \Phi(E \backslash A) \cap \Psi(A)=\emptyset .
$$

Zbiór $A$ jest otwarty typu $\Phi$, jeśli $A \subset \Phi(A)$ i domknięty typu $\Psi$, jeśli $\Psi(A) \subset A$. Mając powyższe definicje, Kempisty zajmował się złożeniami tych operacji, ich monotonicznością, addytywnością i multiplikatywnością.

4.1. Pierwsze prace Stefana Kempistego. Pierwsze trzy prace Kempistego zostały opublikowane w czasopiśmie „Wektor”. Było to jedno z pierwszych polskich czasopism specjalistycznych, które miało służyć pewną pomocą w pracy dydaktycznej nauczycielom matematyki i fizyki. Wydawano je w latach 1911-1918, a więc w okresie, kiedy naród polski żył i rozwijał się w warunkach niewoli.

Pierwsza praca Kempistego [K1] ukazała się w 1916 roku. Dotyczyła ona formalnego przedstawienia permutacji wielościanowych, czyli permutacji związanych z wierzchołkami wielościanów, ale bez odniesienia się do własności metrycznych tych wielościanów. Rok później w tym samym czasopiśmie Kempisty opublikował pracę związaną z płaską geometrią opisową [K2]. Zajmował się w niej podstawowymi założeniami geometrii płaskiej, takimi jak postulaty Hilberta (pewniki połączenia i 
pewniki uporządkowania). Rozważał także postulaty opisowe geometrii liniowej Russella. Kempisty przytoczył ich dosłowną wersje i dołączył swoje objaśnienia, aby następnie dojść do układu o pojęciach i przesłankach logicznie najprostszych [K2], tzn. takich, które były bardziej sformalizowane, spójne i niesprzeczne. W następnych dwóch pracach ([K3], [K4]) zajmował się indukcją matematyczną i teorią liczb. Wszystkie te prace napisane były w języku polskim i wskazywały na dużą wiedzę autora, czerpaną z najnowszych artykułów matematyków zagranicznych, takich jak Bertrand Russell, Henri Lebesgue, René-Louis Baire, Oswald Veblen, David Hilbert.

4.2. Klasyfikacje Baire'a, Younga i Sierpińskiego. W monografii Baire'a [5] można znaleźć dobrze znaną klasyfikację funkcji, według której:

1. funkcje ciągłe tworzą klasę zerową,

2. funkcja należy do klasy $\alpha$, jeżeli jest granicą ciągu funkcji należących do klas o numerach mniejszych niż $\alpha$ (o ile sama nie należy do jednej z tych klas).

Suma skończonej liczby funkcji klasy $\alpha$ także jest funkcją klasy $\alpha$. Jeżeli zamiast o granicy ciągu będziemy mówić o sumie szeregu oraz rozważymy szeregi bezwzględnie zbieżne, to otrzymamy klasyfikację Sierpińskiego. Kempisty nazwał te nowe klasy klasami bezwzględnymi.

Inną klasyfikację funkcji przedstawił W. H. Young ${ }^{14}$, który wykorzystał ciągi monotoniczne. Granice ciągów nierosnących funkcji ciągłych nazywał funkcjami typu $u$ (gdyż są to funkcje półciągłe z góry: upper semi-continuous functions), zaś granice ciągów niemalejących funkcji ciągłych - funkcjami typu $l$ (lower semi-continuous). Granice ciągów nierosnących (niemalejących), których wyrazami są funkcje typu $l$, oznaczał przez $u l(l l)$, itd. (na początku zawsze stawiał literę odpowiadajacą ostatniemu ciągowi).

Oznaczenia te są dla Younga wystarczające, ponieważ rozważa on jedynie funkcje otrzymane za pomocą skończonej liczby przejść granicznych. Klasyfikację Younga można uprościć, nie wymagając by wyrazy ciągu były jednego typu (skoro jest ich nieskończenie wiele, to można wybrać podciąg jednego typu). W pracy Hahna ${ }^{15}$ [30], funkcje klasy Younga $\alpha$ są nazywane funkcjami rzędu $\alpha$. Zgodnie z powyższym funkcje ciągłe są klasy 0, granice ciągów monotonicznych rzędu mniejszego

\footnotetext{
${ }^{14}$ William Henry Young (1863-1942).

${ }^{15}$ Hans Hahn (1879-1934).
} 
niż $\alpha$ są rzędu $\alpha$ (o ile same nie są niższego rzędu). Funkcje rzędu $\alpha$ są typu $l$ lub $u$ zależnie od tego, czy są granicami ciągów niemalejących, czy nierosnących.

W drugim tomie „Fundamenta Mathematicae” znajdujemy dwie prace Kempistego: [K5], [K6].

W pierwszej z nich Kempisty zajął się klasyfikacją funkcji przedstawioną przez Baire'a i pokazał, że każda funkcja pierwszej klasy Baire'a jest granicą nierosnącego (niemalejącego) ciągu funkcji półciągłych z dołu (z góry). Udowodnił także, że każda funkcja będąca granicą monotonicznego ciągu funkcji półciągłych tego samego typu jest rozwijalna w szereg bezwzględnie zbieżny funkcji ciągłych. Wynika stąd, że każdą funkcję pierwszej klasy Baire'a można przedstawić w postaci szeregu bezwględnie zbieżnego funkcji ciągłych, zatem jest drugiej klasy Sierpińskiego. Równocześnie, ponieważ każda funkcja półciągła jest granicą monotonicznego ciągu funkcji ciągłych, jest pierwszej klasy Younga. Okazuje się, że klasyfikacje Baire'a, Younga i Sierpińskiego obejmują wszystkie funkcje przedstawialne analitycznie (tzn. takie, które można przedstawić za pomocą dodawania, mnożenia, przejścia do granicy), co wynika z faktu, że zachodzą twierdzenia:

1. Każda funkcja $\alpha$ klasy Baire'a jest co najwyżej funkcją $\alpha+1$ rzędu Younga $\alpha$ (obu możliwych typów).

2. Każda funkcja $\alpha$ rzędu Younga jest co najwyżej $\alpha$ klasy bezwzględnej (Sierpińskiego).

3. Każda funkcja $\alpha$ klasy Baire'a jest co najwyżej funkcją $\alpha+1$ klasy Sierpińskiego.

Operując współczesnym językiem matematycznym, możemy $\alpha$ klasy Baire'a $\left(B_{\alpha}\right)$ i Sierpińskiego $\left(S_{\alpha}\right)$ opisać w następujący sposób:

Jeżeli $f: X \rightarrow \mathbb{R}$, gdzie $X$ jest przestrzenią metryczną, to:

$$
\begin{aligned}
B_{0}(X)= & S_{0}(X)=C(X)-\text { klasa funkcji ciągłych, } \\
B_{\alpha}(X)= & \left\{\lim _{n \rightarrow \infty} f_{n}:\left(f_{n}\right) \text { ciąg zbieżny dla każdego } x \in X,\right. \\
& \left.f_{n} \in B_{\alpha_{n}}(X) \text { dla } \alpha_{n}<\alpha\right\}, \\
S_{\alpha}(X)= & \left\{\sum_{n=1}^{\infty} f_{n}: \sum_{n=1}^{\infty}\left|f_{n}\right|<\infty \text { dla każdego } x \in X,\right. \\
& \left.f_{n} \in S_{\alpha_{n}}(X) \text { dla } \alpha_{n}<\alpha\right\} .
\end{aligned}
$$


Wówczas $S_{1}(X)$ jest klasą różnic funkcji półciągłych z góry (lub z dołu). Oczywiście $S_{\alpha}(X) \subset B_{\alpha}(X)$ dla każdego $\alpha<\omega_{1}$.

W pracy $[K 5]$ Kempisty postawił problem, czy $S_{\alpha}([0,1]) \neq B_{\alpha}([0,1])$ dla każdego takiego $\alpha$, że $1 \leqslant \alpha<\omega_{1}$. W. Sierpiński [74] i S. Mazurkiewicz [55] niezależnie od siebie pokazali, że $S_{1}([0,1]) \neq B_{1}([0,1])$. Natomiast problem Kempistego dla $\alpha>1$ został rozwiązany przez Michała Morayne'a w 1992 roku w pracy [58]. Pokazał on, że w klasie Baire'a funkcji mierzalnych $\mathrm{w}$ sensie Borela określonych na pewnej nieprzeliczalnej przestrzeni polskiej istnieje funkcja, której nie da się przedstawić w postaci przeliczalnej sumy funkcji będących $\alpha$ klasy Sierpińskiego. Ponadto dla każdego $\alpha<\omega_{1} \mathrm{w} \alpha$ klasie Sierpińskiego istnieje funkcja, której nie można przedstawić w postaci przeliczalnej sumy funkcji, z których każda jest jednego z typów $\alpha$ klasy Younga (przy czym Morayne nie zakładał, że klasy o numerach różnych są rozłączne). Streszczenie pracy [K5] było opublikowane w [K7], a pełna wersja polska w [K8]. O pracy [K5] wspomina Medvedev w książce [56] przy opisie historii funkcji rzeczywistych.

W pracy [K6] Kempisty zajął się wynikami Mazurkiewicza oraz de la Vallée Poussina (uzyskanymi niezależnie). Pokazali oni, że dla każdej ograniczonej funkcji $f$ określonej na zbiorze liczb rzeczywistych, pierwszej klasy Baire'a, oraz dowolnego $\varepsilon>0$ istnieje taka funkcja $\varphi$ będąca różnicą dwóch funkcji półciągłych z góry, że

$$
|f(x)-\varphi(x)|<\varepsilon \text { dla } x \in \mathbb{R} .
$$

Stefan Kempisty wynik ten uogólnił, rozszerzając go na funkcje nieograniczone.

Twierdzenie 1 (Kempisty, 1921) Niech $f$ będzie funkcją pierwszej klasy Baire'a. Wówczas dla dowolnego $\varepsilon>0$ istnieje funkcja $\chi(x)$ będąca różnicą dwóch funkcji półciągłych z góry i taka, że $|f(x)-\chi(x)|<\varepsilon$.

Aby udowodnić to twierdzenie, Kempisty najpierw pokazał, że jeżeli $f_{1}, f_{2}$, gdzie $f_{1}<f_{2}$, są funkcjami pierwszej klasy Baire'a, to istnieje taka funkcja $f$ będąca różnicą dwóch funkcji półciągłych z góry, że

$$
f_{1}(x) \leqslant f(x) \leqslant f_{2}(x) .
$$

Wówczas dla $f_{1}(x)=f(x)-\varepsilon$ oraz $f_{2}(x)=f(x)$ istnieje funkcja $\chi(x)=\varphi(x)-\psi(x)(\varphi, \psi-$ półciągłe $\mathrm{z}$ góry $)$ spełniająca nierówności $f_{1}(x) \leqslant \chi(x) \leqslant f_{2}(x)$.

Twierdzenie to zostało uogólnione przez Sierpińskiego w [75] w następujący sposób: jeśli $f: \mathbb{R} \rightarrow \mathbb{R}$ jest klasy mniejszej lub równej $\alpha$, to 
dla dowolnej liczby $\varepsilon>0$ istnieje taka funkcja $g: \mathbb{R} \rightarrow \mathbb{R}$ klasy mniejszej lub równej $\alpha$, że $g(x)$ jest wielokrotnością $\varepsilon$ dla każdego $x \in \mathbb{R}$ oraz $|f(x)-g(x)|<\varepsilon$ dla każdego $x \in \mathbb{R}$.

Kempisty badał funkcje pierwszej klasy Baire'a i w pracy [K6] pokazał, jak między dwie funkcje tej klasy, $f_{1}$ i $f_{2}, f_{1}<f_{2}$, wprowadzić funkcję $f\left(f_{1} \leqslant f \leqslant f_{2}\right)$ będącą różnicą dwóch funkcji półciągłych z góry.

Rozważania dotyczące funkcji będącej różnicą dwóch funkcji półciągłych z góry możemy znaleźć we wcześniejszej pracy Sierpińskiego [74], w której pokazał, że funkcja rzeczywista jednej zmiennej rzeczywistej jest rozwijalna w szereg bezwzględnie zbieżny wtedy i tylko wtedy, gdy jest różnicą dwóch funkcji półciągłych z góry (czyli pierwsza klasa Sierpińskiego składa się z różnic funkcji półciągłych z góry).

Twierdzenia Mazurkiewicza, Sierpińskiego i Kempistego z [K6] były uogólniane w pracach [63] i [82].

W 1908 roku Young udowodnił twierdzenie, które nazwał „Rome theorem", ponieważ było prezentowane w Rzymie na międzynarodowej konferencji. Było to jedno z pierwszych twierdzeń dotyczących zupełnie dowolnej funkcji, nieposiadającej żadnych dodatkowych własności. Dla dowolnej funkcji rzeczywistej jednej zmiennej rzeczywistej przez $C^{+}(f, x)$ Young oznaczył zbiór wszystkich liczb będących granicami ciągów $f\left(x_{n}\right)$ dla $x_{n} \rightarrow x+$. Analogicznie: $C^{-}(f, x)$ to zbiór wszystkich liczb będących granicami ciągów $f\left(x_{n}\right)$ dla $x_{n} \rightarrow x-$. Young udowodnił, że dla dowolnej funkcji $f$ istnieje taki zbiór przeliczalny $E$, że równość $C^{-}(f, x)=C^{+}(f, x)$ zachodzi dla wszystkich $x \in \mathbb{R} \backslash E$.

$\mathrm{W}$ pracy [K10] Kempisty zamiast zwykłych granic rozważał granice aproksymatywne i udowodnił, że zbiór punktów, w których granice aproksymatywne: lewo- i prawostronna dowolnej funkcji $f: \mathbb{R} \rightarrow \mathbb{R}$ istnieją i są różne, jest co najwyżej przeliczalny. Rezultat ten jest cytowany np. w [11, str. 346] i w [78, str. 12].

Przypomnijmy, że $y$ jest granicą aproksymatywną funkcji $f$ w punkcie $x_{0}$, jeżeli istnieje taki zbiór mierzalny $A$, że

$$
\lim _{h \rightarrow 0+} \frac{m\left(A \cap\left[x_{0}-h, x_{0}+h\right]\right)}{2 h}=1 \text { orazy }=\lim _{x \in A, x \rightarrow x_{0}} f(x) .
$$

W 1925 roku Sierpiński [76] podał przykład funkcji dwóch zmiennych półciągłej z góry ze względu na każdą zmienną, która nie była mierzalna. Kempisty w [K22] pokazał, że mierzalność funkcji jest zachowana, jeżeli funkcja jest półciągła z góry ze względu na jedną zmienną i półciągła z dołu ze względu na drugą. Dokładniej Kempisty udowodnił, że: 
Twierdzenie 2 (Kempisty, 1929) Jeżeli $f: \mathbb{R}^{2} \rightarrow \mathbb{R}$ jest półciągła z góry ze względu na jedną zmienną i półciągła z dołu ze względu na drugą zmienną, to jest co najwyżej pierwszej klasy Baire'a.

Dowód przebiegał w kilku etapach. Najpierw Kempisty pokazał, że jeżeli $f$ jest półciągła $z$ dołu ze względu na $x$, zaś $M_{k}^{(y)}\left(x_{0}, y_{0}\right)$ oznacza granicę górną funkcji $\varphi(y)=f\left(x_{0}, y\right)$ na przedziale $y \in\left(y_{0}-k, y_{0}+k\right)$, gdzie $k \in \mathbb{R}$, to $M_{k}^{(y)}$ (jako funkcja dwóch zmiennych) jest półciągła z dołu. Jeżeli $m_{k}^{(y)}\left(x_{0}, y_{0}\right)$ oznacza granicę dolną funkcji $\varphi$ na tym samym przedziale i $f$ jest półciągła z góry ze względu na $x$, to $m_{k}^{(y)}$ jest funkcją półciągłą z góry. W dowodzie twierdzenia dla ustalenia uwagi Kempisty założył, że $f$ jest półciągła $z$ dołu ze względu na $x$ i półciągła $z$ góry ze względu na $y$. Kempisty zauważył, że dla każdego $n \in \mathbb{N}$

$$
m_{\frac{1}{n}}^{(x)}(x, y) \leqslant f(x, y) \leqslant M_{\frac{1}{n}}^{(y)}(x, y) .
$$

Ponadto ciąg $\left\{M_{\frac{1}{n}}^{(y)}\right\}_{n \in \mathbb{N}}$ jest nierosnący, więc $M^{(y)}=\lim _{n \rightarrow \infty} M_{\frac{1}{n}}^{(y)}$ jest granica nierosnącego ciągu funkcji półciągłych z dołu. Podobnie $m^{(x)}=$ $\lim _{n \rightarrow \infty} m_{\frac{1}{n}}^{(x)}$ jest granicą niemalejącego ciągu funkcji półciągłych z góry. Zatem $M^{(y)}$ jest typu $u l$, zaś $m^{(x)}$ jest typu $l u \mathrm{w}$ klasyfikacji Younga. Ponieważ $m_{\frac{1}{n}}^{(x)} \leqslant M_{\frac{1}{n}}^{(y)}$ oraz $m_{\frac{1}{n}}^{(x)}$ jest półciągła z góry, zaś $M_{\frac{1}{n}}^{(y)}$ jest półciągła z dołu, więc dla każdego $n \in \mathbb{N}$ istnieje taka funkcja ciągła $f_{n}$, że

$$
m_{\frac{1}{n}}^{(x)}(x, y) \leqslant f_{n}(x, y) \leqslant M_{\frac{1}{n}}^{(y)}(x, y)
$$

dla $(x, y) \in \mathbb{R}^{2}$. Otrzymujemy ciąg funkcji ciągłych $\left\{f_{n}\right\}_{n \in \mathbb{N}}$ zbieżnych do funkcji $f$, czyli $f$ jest co najwyżej pierwszej klasy Baire'a.

Rezultat ten jest cytowany w pracach [1], [48] i [78].

Funkcjami Baire'a Kempisty zajmował się także w [K17], natomiast pewne uogólnienia funkcji półciągłych (Kempisty nazywał je funkcjami relatywnie półciągłymi lub półciągłymi względem pewnej funkcji) rozważał także w pracy [K34].

Klasyfikacja Baire'a i Younga pojawia się także w pracy [K31], gdzie Kempisty zajmował się klasyfikacją pochodnych cząstkowych funkcji dwóch zmiennych, a także mierzalnością pochodnych Diniego. W 1922 roku S. Banach udowodnił, że pochodne Diniego funkcji mierzalnej są mierzalne. Przykładem funkcji z niemierzalnymi pochodnymi Diniego jest funkcja charakterystyczna zbioru niemierzalnego.

J.C. Burkill i U.S. Haslam-Jones w 1932 roku wykazali mierzalność pochodnych cząstkowych funkcji mierzalnej dwóch zmiennych, natomiast Kempisty udowodnił (zob. [K31, Tw. 5]), że jeżeli $f(x, y)$ jest 
mierzalną funkcją określoną na zbiorze $E$, to ekstremalne pochodne cząstkowe $\underline{D}_{x} f$ i $\bar{D}_{x} f$ są mierzalne w $E$.

4.3. Funkcje quasi-ciągłe w sensie Kempistego. Wygląda na to, że pojęcie funkcji quasi-ciagłej w sensie Kempistego, opublikowane w 1932 roku w pracy [K29], stało się trwałą nazwą, bowiem praca ta jest najczęściej cytowaną jego pracą. Wywarła ona ogromny wpływ na prace wielu matematyków.

Pojęcie było wprowadzone już w 1931 roku w odczycie Kempistego na II Kongresie Matematyków Polskich w Wilnie we wrześniu 1931 roku. Odnotujmy w tym miejscu że, jak napisał Kempisty w swojej pracy [K29, str. 184] pojęcie quasi-ciągłości ma swój początek w pracy Hahna [29, str. 310], jednak pojęcie quasi-ciągłości było prawdopodobnie po raz pierwszy użyte przez Baire'a w 1899 roku w jego pracy [4, str. 98] w związku z badaniem punktów ciągłości funkcji z $\mathbb{R}^{2}$ do $\mathbb{R}$, ciągłych ze względu na każdą zmienną z osobna (zob. też [68, str. 91]).

Definicja 1 (Kempisty, 1932) Funkcja $f: \mathbb{R} \rightarrow \mathbb{R}$ jest quasi-ciągła (w sensie Kempistego), jeśli dla każdego $\varepsilon>0$, każdej liczby rzeczywistej $x$ i jej otwartego otoczenia $U$ istnieje taki otwarty i niepusty podzbiór $V$ zbioru $U$, że $|f(x)-f(y)|<\varepsilon$ dla wszystkich $y$ należących do $V$.

Wszystkie funkcje ciągłe, jak również wszystkie funkcje lewo- i prawostronnie ciągłe, są quasi-ciągłe. Funkcją quasi-ciągłą jest także funkcja $f: \mathbb{R} \rightarrow \mathbb{R}$ dana wzorem

$$
f(x)= \begin{cases}0 & \text { dla } x \neq 0 \\ 1 & \text { dla } x=0\end{cases}
$$

która jest obustronnie nieciągła w punkcie 0 .

W pracy [K32] Kempisty wprowadził pojęcia quasi-ciągłości i symetrycznej quasi-ciągłości funkcji $f(x, y)$ na przestrzeni $X \times Y$, gdzie $X$ i $Y$ są skończonymi produktami przestrzeni metrycznych.

W 1961 roku definicja Kempistego została uogólniona przez N. Martina [53] na dowolne przestrzenie topologiczne $X, Y$ : funkcja $f: X \rightarrow Y$ jest quasi-ciagła, jeżeli przeciwobraz dowolnego zbioru otwartego jest quasi-otwarty, tzn. ma gęste wnętrze. W tym samym roku S. Marcus pokazał [52], że istnieje funkcja quasi-ciągła $f:[0,1] \rightarrow \mathbb{R}$, która nie jest mierzalna w sensie Lebesgue'a. W tej samej pracy udowodnił także, że dla każdej liczby porządkowej $\alpha<\omega$ istnieje funkcja quasi-ciągła $f:[0,1] \rightarrow \mathbb{R}$, która należy do $\alpha$ klasy Baire'a i nie należy do żadnej klasy Baire'a o numerze niższym od $\alpha$. 
Kempisty zdefiniował też symetryczna quasi-ciagłość funkcji oraz udowodnił klasyczne twierdzenie o quasi-ciągłości funkcji dwóch zmiennych rzeczywistych.

Twierdzenie 3 (Kempisty, 1932) Niech $f: \mathbb{R}^{2} \rightarrow \mathbb{R}$. Jeżeli funkcje $f_{x}(\cdot)=f(x, \cdot)$ i $f^{y}(\cdot)=f(\cdot, y)$ są quasi-ciągłe na $\mathbb{R}$, to funkcja $f$ jest quasi-ciągła na $\mathbb{R}^{2}$.

Szerokie opracowanie quasi-ciągłości wraz z wieloma uogólnieniami (np. dotyczącymi multifunkcji) zostało przedstawione przez Neubrunna w [61].

Praca Kempistego [K29] spowodowała rozważanie i badanie innego typu nieciągłości (w tym też wyżej wspomnianego klasycznego twierdzenia Kempistego) jak np.: klikowość, półciągłość, prosta ciągłość, pseudociągłość, prawie ciągłość etc. Badali je (chronologicznie) Bledsoe [8], Thielman [79], Marcus [52], Levine [46], Neubrunnova [62], Grande [27], Seweryn-Kuzmanovska i Chalamani [73].

Praca Kempistego [K29] jest cytowana w książkach takich autorów jak np. Bruckner [9], Hart-Nagata [31], Thomson [80] oraz w wielu pracach, m.in. w [2], [15], [19], [25]-[27], [35], [44], [45], [47], [49]-[51], [53], [57], [59]-[62], [68], [73] i [78].

4.4. Aproksymatywna ciągłość. Funkcje aproksymatywnie ciągłe wprowadził i badał Denjoy [20] w 1918 roku w swojej pracy o pochodnych. Funkcja $f$ zdefiniowana w otoczeniu $x_{0}$ jest aproksymatywnie ciagła w punkcie $x_{0}$, jeżeli zbiór $\left\{x \in E:\left|f(x)-f\left(x_{0}\right)\right|<\varepsilon\right\}$ posiada $\mathrm{w}$ tym punkcie gęstość równą jeden niezależnie od $\varepsilon>0$.

Denjoy udowodnił m.in., że funkcja mierzalna i ograniczona w przedziale $[a, b]$ jest równa pochodnej swej całki w każdym punkcie, w którym jest aproksymatywnie ciągła (dowód znajdujemy też u Kempistego w [K15, str. 18-19] oraz w książce [10, Tw. 7.36 na str. 317]).

Kempisty w [K15] zdefiniował quasi-aproksymatywną ciągłość: funkcja $f$ nazywa się quasi-aproksymatywnie ciagła w punkcie $x_{0}$, jeżeli zbiór $\left\{x \in E:\left|f(x)-f\left(x_{0}\right)\right|<\varepsilon\right\}$ posiada w tym punkcie górną gęstość równą jeden niezależnie od $\varepsilon>0$. Udowodnił też analogon twierdzenia Denjoy $\mathrm{w}[\mathrm{K} 15$, str. 25-26].

Twierdzenie 4 (Kempisty, 1925) Funkcja ograniczona w przedziale $[a, b]$ jest równa liczbie pochodnej swej całki w każdym punkcie, w którym jest quasi-aproksymatywnie ciągła.

Zarówno praca [K15], jak i jej wersja skrócona [K11], wpłynęły do czasopism w grudniu 1922 roku, ale pierwsza z nich została opublikowana dopiero w 1925 roku. Praca ta była rozprawą habilitacyjną Kempistego. 
Kolejne prace Kempistego dotyczące aproksymatywnej ciągłości funkcji rzeczywistych to: [K12], [K16], [K20]. Są one związane z jego wcześniejszymi pracami [K9], [K10], [K15].

W pracy [K12] z 1925 roku Kempisty podał określenie skrajnych granic aproksymatywnych oparte na pojęciu kresów z pominięciem zbiorów o gęstości $\lambda$ dla $\lambda \in(0,1)$ oraz udowodnił, że granice skrajnie aproksymatywne należa do trzeciej klasy Younga. Ponadto uprościł dowody twierdzenia Denjoy (1915, [20, str. 183]): Funkcja aproksymatywnie ciagła jest pierwszej klasy Baire'a oraz twierdzenia Caratheodory'ego (1918, [14, str. 406]): Funkcja mierzalna jest prawie wszedzie równa funkcji drugiej klasy Younga.

W pracy [K16] Kempisty udowadnia uogólnienia twierdzenia Newmana o pochodnych funkcji o wahaniu ograniczonym (1923): Pochodna regularna sumowalna dowolnej funkcji zbioru jest aproksymatywnie ciagła i znane twierdzenie Denjoy (1915, [20, str. 173]): Funkcja aproksymatywnie ciagła ograniczona jest regularna pochodna swej catki na zbiorze.

W pracy [K20] Kempisty podał nową własność pochodnych regularnych. Z tej własności wynika ciągłość w sensie Darboux: pochodnej funkcji jednej zmiennej oraz funkcji aproksymatywnie ciagłej.

W 1922 roku W. Sierpiński pokazał, że zbiór punktów, w których $f_{+}(x) \neq f_{-}(x)$, jest przeliczalny, natomiast w 1924 roku Kempisty [K10] uzyskał analogiczny rezultat dla zbioru punktów, w których np. górna granica aproksymatywna prawostronna jest mniejsza od dolnej granicy aproksymatywnej lewostronnej.

4.5. Całka Kempistego. Niech funkcja $F:[a, b] \rightarrow \mathbb{R}$ będzie różniczkowalna. Wiadomo, że gdy pochodna $F^{\prime}$ jest całkowalna w sensie Riemanna, to

$$
\int_{a}^{x} F^{\prime}(t) d t=F(x)-F(a) \quad \text { dla każdego } x \in[a, b],
$$

ale a priori $F^{\prime}$ nie musi być całkowalna w sensie Riemanna. Jeśli weźmiemy całkę Lebesgue'a zamiast całki Riemanna, to nadal potrzeba, by $F^{\prime}$ była całkowalna w sensie Lebesgue'a, a wiadomo, że istnieją funkcje $F^{\prime}$, które nie są w tym sensie całkowalne.

Poszukiwania takiej definicji całki na przedziale $[a, b]$, aby każda pochodna $F^{\prime}$ była całkowalna na $[a, b]$ oraz aby zachodziła formuła (1) doprowadziły do zdefiniowania całki Denjoy w 1912 roku (tzw. całka Denjoy w wąskim sensie), Perrona w 1914 roku, Henstocka i Kurzweila (1955 i 1957). Okazało się jednak, że wszystkie te definicje są równoważne. 
W latach trzydziestych w [K30] Kempisty zdefiniował dwuwymiarową całkę Denjoy zwaną czasami całka Denjoy-Kempistego lub całka Kempistego. W [K37] teorię tę rozwinął na przypadek $n$-zmiennych w następujący sposób. Dane są zbiór $R$ oraz rodzina $\mathcal{S}$ wszystkich przedziałów $I=\left[a_{1}, b_{1}\right] \times \ldots \times\left[a_{n}, b_{n}\right] \subset \mathbb{R}^{n}$, które nie mają wspólnych punktów wewnętrznych. Podziałem zbioru $R$ nazywamy taką skończoną podrodzinę $\mathcal{S}_{0}$ rodziny $\mathcal{S}$, że $R=\bigcup_{\mathcal{S}_{0}} I$. Przez $|I|$ oznaczamy miarę, zaś przez $p(I)$ współczynnik regularności przedziału $I$, czyli iloraz $|I| /|K|$, gdzie $K$ jest najmniejszą kostką zawierającą $I$. Największą z liczb $p(I)$ dla $I \in \mathcal{S}$ nazywamy współczynnikiem regularności rodziny $\mathcal{S}$. Rozważamy addytywną, ciągłą w sensie Saksa funkcję przedziału $F(I)$ (tzn. $F(I) \rightarrow 0$ dla $|I| \rightarrow 0$ ) określoną na $\mathcal{S}$. Jeżeli dla ustalonego współczynnika regularności $p(\mathcal{S})$ oraz dla każdego podziału $\mathcal{S}_{0}$ zbioru $R$ istnieje i jest skończona granica sumy $\sum_{I \in \mathcal{S}_{0}} F(I)$, to nazywamy jac całką Kempistego.

Funkcję $F$ całkowalną dla $p(\mathcal{S})=\frac{1}{2}$ Kempisty nazywał regularnie całkowalną. W pracy [K30] Kempisty badał własności tak zdefiniowanej całki i udowodnił, że każda funkcja ciągła jest regularnie całkowalna. Ponadto pokazał, że jego całka jest funkcją addytywną i jednorodną oraz że każda funkcja $F$ regularnie całkowalna na $R$ jest regularnie całkowalna na dowolnym zbiorze $R_{0} \subset R$.

Wyniki Kempistego zostały wykorzystane przez Ralpha Henstocka w jego pracy doktorskiej [33]. Jeden z rozdziałów tej pracy (rozdział 3 zatytułowany Special functions) został skonstruowany analogicznie do pracy [K30]. Henstock rozważał w nim pewne typy całek funkcji przedziału oraz badał ich własności dla funkcji o wahaniu skończonym, funkcji absolutnie ciągłych, absolutnie półciągłych, całkowalnych względem dowolnego zbioru $E$.

Całce Kempistego został poświęcony cały rozdział pracy K. Ostaszewskiego [66] (rozdział 4 zatytułowany The integral of Kempisty), w którym została przedstawiona definicja całki dla współczynnika regularności $p(\mathcal{S}) \geqslant \rho$, gdzie $\rho$ jest ustaloną liczbą przedziału $(0,1)$. Ostaszewski pokazał, że każda funkcja całkowalna w sensie Kempistego jest całkowalna w sensie Lebesgue'a na pewnym niezdegenerowanym przedziale domkniętym. Przedstawił również definicję całki Kempistego za pomocą odpowiedniej bazy różniczkowania.

Kempisty zajmował się całkami także w pracach [K13], [K14], [K18], [K19], [K23], [K26], [K27], przy czym najważniejsze ich własności przedstawił w [K13], [K23], [K26].

O całce Kempistego bądź całce Kempistego-Denjoy wspomina się 
np. w książkach [6], [7], [16] i [66] oraz w pracach [12], [13], [33], [64] i [65].

4.6. Funkcje przedziału. W pracach związanych z całkami Kempisty rozważał często funkcje przedziału (np. [K19]-[K21], [K26]-[K28], [K36], [K37], [K39]) i badał ich własności. W pracy [K30] zdefiniował funkcje przedziału absolutnie ciągłe, absolutnie półciągłe (z góry i z dołu), uogólnione rodzaje tych funkcji, funkcje o wahaniu ograniczonym oraz pochodną funkcji przedziału.

Niech $\mathcal{S}$ będzie dowolnym układem elementarnym pokrywającym zbiór $R \subset \mathbb{R}^{n}$, czyli skończoną rodziną przedziałów domkniętych niezachodzących na siebie zawartych w $R$, zaś $F$ funkcją przedziału określoną na $\mathcal{S}$. Wówczas $F$ jest absolutnie ciągła na $R$, jeżeli

$$
\forall \varepsilon>0 \exists \delta=\delta(\varepsilon)>0(|\mathcal{S}|<\delta \Rightarrow|F(\mathcal{S})|<\varepsilon) .
$$

Jeżeli współczynnik regularności układu $\mathcal{S}$ nie przekracza $\frac{1}{2}$, to mówimy, że funkcja $F$ jest regularnie absolutnie ciągła.

Kempisty pokazał, że jeżeli funkcja $F$ jest regularnie całkowalna, to jest regularnie absolutnie ciągła.

Jeżeli w definicji funkcji (regularnie) absolutnie ciągłej warunek $|F(\mathcal{S})|<\varepsilon$ zastąpimy przez $F(\mathcal{S})>-\varepsilon$, to otrzymamy funkcje (regularnie) absolutnie półciągłą z dołu, jeśli przez $F(\mathcal{S})<\varepsilon$, to mamy funkcję (regularnie) absolutnie półciągłą z góry.

Pochodną funkcji $F$ w punkcie $x \in R$ nazywamy granicę $D F(x)=$ $\lim _{I \rightarrow x} \frac{F(I)}{|I|}$. Analogicznie otrzymujemy pochodną dolną $\underline{D} F(x)$ i górną $\bar{D} F(x)$. Kempisty udowodnił, że jeżeli funkcja $F$ jest absolutnie półciągła z dołu na $R$, to dla dolnej i górnej całki Kempistego zachodzą nierówności:

$$
\int_{\bar{R}} F \geqslant \int_{R} \underline{D} F(x) d x, \int_{R} F \geqslant \int_{R} \bar{D} F(x) d x .
$$

Ponadto, każda osobliwa (tzn. mająca pochodną równą 0 dla prawie wszystkich $x \in R$ ) addytywna funkcja przedziału, która jest regularnie absolutnie ciągła na $R$, jest tożsamościowo równa zero.

Rozdział 3 pracy [K30] poświęcony jest funkcjom przedziału o wahaniu ograniczonym. Mówimy, że funkcja przedziału $F$ ma wahanie ograniczone na $R$, jeżeli górna całka Burkilla $\int_{R}^{\bar{C}}|F|$ jest skończona. Poprzez zamianę całki Burkilla na całkę Kempistego otrzymujemy funkcję o regularnym wahaniu ograniczonym na $R$. Kempisty pokazał, że suma dwóch 
funkcji o regularnym wahaniu ograniczonym jest funkcją o regularnym wahaniu ograniczonym, a każda funkcja regularnie absolutnie ciągła ma regularne wahanie ograniczone. Ponadto, jeżeli funkcja o regularnym wahaniu ograniczonym jest ciągła i nierosnąca, to jest regularnie całkowalna.

Kempisty kontynuował tematykę funkcji absolutnie półciągłych oraz całkowalnych w różnym sensie (np. Riddera, Perrona) w pracy [K39].

Podane definicje i rezultaty Kempistego zostały zauważone i wykorzystane, między innymi w [12], [16], [18], [22], [32] - [34], [64], [65] i [71].

4.7. Teoria pola powierzchni. Wydawałoby się, że korzystając z metody obliczania długości krzywej, w analogiczny sposób możemy obliczać pole $A(S)$ powierzchni ograniczonej $S$. Okazało się jednak, że nie można bezpośrednio przenieść obu definicji długości łuku na przypadek pola powierzchni. Załóżmy, że $S_{k}$ jest dowolnym ciągiem wpisanych wielościanów, których średnice dążą do zera. Jedna definicja stanowiłaby, że pole powierzchni $A(S)$ jest kresem górnym liczb $A\left(S_{k}\right)$ dla wszystkich wielościanów wpisanych (ale wówczas nawet w najbardziej prostych przypadkach otrzymujemy $+\infty)$. Druga definicja określałaby pole $A(S)$ jako granicę ciągu liczb $A\left(S_{k}\right)$, ale wówczas nawet przy założeniu, że średnica takich wielościanów dąży do zera, granica ta nie musiałaby istnieć. Odpowiedni kontrprzykład podali H. A. Schwarz (1880) i G. Peano (1882). Po tym kontrprzykładzie, w 1902 roku, Lebesgue zdefiniował pole powierzchni następująco. Rozważamy wszystkie ciągi wielościanów $S_{k}$, które zbiegają jednostajnie do $S$. Polem powierzchni $S$ nazywamy liczbę $A(S)=\inf \left[\lim _{k \rightarrow \infty} \inf A\left(S_{k}\right)\right]$, gdzie infimum jest brane po wszystkich ciągach powierzchni wielościanów takich, jak założyliśmy wcześniej. W zależności od sposobu przybliżania powierzchni $S$ polami wielościanów wpisanych otrzymujemy definicję według Lebesgue’a i Geöczego. Obie te metody przedstawił T. Radó w pracy [69].

Korzystając z wcześniej wspomnianych metod, otrzymujemy poniższe wzory określające pole powierzchni $S$. Dla dowolnej powierzchni $S$ danej przez funkcję ciągłą $z=f(x, y)$ dla $(x, y) \in P$, gdzie $P$ jest prostokątem $[a, b] \times[c, d]$, przy założeniu, że pochodne cząstkowe $f_{x}$ i $f_{y}$ są ciągłe w $P$, pole tej powierzchni $S$ wynosi

$$
A(S)=\iint_{P} \sqrt{1+\left(f_{x}\right)^{2}+\left(f_{y}\right)^{2}} d x d y .
$$

W przypadku parametrycznych równań powierzchni $S$ danych przez funkcje $x=x(u, v), y=y(u, v), z=z(u, v),(u, v) \in P$, gdzie prostokąt $P=[a, b] \times[c, d]$ jest $\mathrm{w} u v$-płaszczyźnie: jeżeli $x(u, v), y(u, v), z(u, v)$ 
mają ciągłe pochodne cząstkowe w $P$, to pole tej powierzchni $S$ wynosi

$$
A(S)=\iint_{P} \sqrt{X^{2}+Y^{2}+Z^{2}} d u d v,
$$

gdzie $X, Y, Z$ oznaczają jakobiany $X=\frac{\partial(y, z)}{\partial(u, v)}, Y=\frac{\partial(z, x)}{\partial(u, v)}, Z=\frac{\partial(x, y)}{\partial(u, v)}$.

Wzory (2) i (3) nasuwaja pytania w związku z szerszymi klasami powierzchni. Uogólnienia szły w dwóch kierunkach. Przede wszystkim dla powierzchni $S$ opisanej funkcją $x=f(x, y)(\operatorname{gdzie}(x, y) \in D$, $D \subset \mathbb{R}^{2}$ ) starano się osłabić założenia dotyczące istnienia i ciągłości pochodnych cząstkowych i poszukiwano ogólniejszych warunków, by odpowiadająca powierzchnia była skończona i nadal dawała się opisać przez wzór (2). W 1926 roku L. Tonelli udowodnił, że na to, by pole powierzchni $z=f(x, y)$ było skończone, potrzeba i wystarcza, by funkcja $f$ była funkcją o wahaniu skończonym (wahanie w sensie Tonellego). Odnotujmy, że jeśli powierzchnia $z=f(x, y)$ ma pole skończone, to pochodne cząstkowe $f_{x}$ i $f_{y}$ istnieją prawie wszędzie i całka (2) istnieje w sensie Lebesgue'a. Tonelli (1926) wykazał także, że jeżeli powierzchnia $S$ ma skończoną miarę Lebesgue'a, $f$ jest funkcją o skończonym wahaniu w $D$, pochodne cząstkowe $f_{x}, f_{y}$ istnieją prawie wszędzie w $D$ i są całkowalne w sensie Lebesgue'a w $D$, to

$$
A(S) \geqslant \iint_{D} \sqrt{1+\left(f_{x}\right)^{2}+\left(f_{y}\right)^{2}} d x d y,
$$

przy czym równość zachodzi wtedy i tylko wtedy, gdy $f$ jest absolutnie ciągła w $D$ (zob. [71, Chapter VI]).

Drugi kierunek uogólnień dotyczył powierzchni opisanych wzorami parametrycznymi. Okazało się, że wzór (3) zachodzi, gdy funkcje opisujące $S$ spełniają warunek Lipschitza, ale nie był znany ogólny warunek konieczny i dostateczny na to, żeby pole powierzchni $S$ było skończone i ewentualnie dawało się opisać wzorem (3).

W pracy [K38] Stefan Kempisty podał zastosowanie funkcji prostokąta (analogicznej do funkcji przedziału) do wyznaczania pola powierzchni $z=f(x, y),(x, y) \in S$. Dla ustalonego $h, k>0$ rozważamy prostokąt $R=[a, a+h] \times[b, \leqslant b+k]$. Mówimy, że jest on semi-regularny, jeżeli $1 / 2 \leqslant h / k \leqslant 2$. Zakładamy, że powierzchnia $S$ daje się pokryć takimi semi-regularnymi prostokątami $R_{1}, \ldots R_{n}$, że nie mają one wspólnych punktów wewnętrznych oraz że $F$ jest addytywną funkcją prostokąta. Analogicznie jak w rozdziale 4.6 Kempisty badał semi-regularną całkę funkcji $F$ na powierzchni $S$ oraz funkcje absolutnie semi-regularne. Udowodnił, między innymi, następujące twierdzenie: 
Twierdzenie 5 (Kempisty, 1936) Jeżeli $F$ jest semi-regularnie absolutnie ciągła, to

$$
\int_{\bar{Q}} F=\iint_{Q} \sqrt{X^{2}+Y^{2}+Z^{2}} d u d v .
$$

W tej samej pracy, rozszerzył swoją metodę na trójkąty w następujący sposób: prostokąt $R$ dzielimy na dwa trójkąty prostokątne $T_{1}$ i $T_{2}$, przy czym trójkąt $T_{1}$ ma wierzchołki $(a, b),(a+h, b)$ i $(a+h, b+k)$, zaś wierzchołkami $T_{2}$ sac punkty $(a, b),(a, b+h)$ i $(a+h, b+k)$. Wpisywane wielościany miały trójkątne ściany i ich rzuty na płaszczyznę $x y$ były wymienionymi wcześniej trójkątami $T_{1}$ i $T_{2}$. Kempisty pokazał, że wprowadzenie funkcji trójkąta pozwoliło na rozszerzenie klas powierzchni, do których stosuje się jego metoda (nazywana metodą triangulacji).

Kempisty kontynuował swoje rozważania w pracy [K42], która dotyczyła pola Lebesgue'a $A(S)$ powierzchni $S$ danej równaniami parametrycznymi $x=x(u, v), y=y(u, v), z=z(u, v)$, gdzie podane funkcje są ciągłe na kwadracie $Q: 0 \leqslant u, v \leqslant 1$ i mają pochodne cząstkowe prawie wszędzie w $Q$.

Rezultaty Kempistego [K35], [K38], [K40]-[K42] zostały zauważone w książkach (chronologicznie): Saksa [72], Radó [70] i Cesari [17] oraz w pracach: Frécheta [23], Toralballa [81], Alperta-Toralballa [3] i Grandona-Perrina [24].

4.8. Przestrzenie Kempistego. Pojęcie quasi-ciągłości wprowadzone w pracy [K29] posłużyło do zdefiniowania przestrzeni Kempistego. Definicję tę wprowadził w 1999 roku, w swojej pracy habilitacyjnej, V. K. Maslyuchenko (zob. [54], po ukraińsku). Możemy ją także znaleźć w bardziej dostępnym artykule [59] z 2006 roku napisanej przez V. V. Mykhaylyuka, współautora wielu artykułów V. K. Maslyuchenki.

Przestrzeń topologiczną $Y$ nazywamy przestrzenia Kempistego, jeżeli dla każdej przestrzeni Baire'a $X$ każda funkcja $f: X \times Y \rightarrow \mathbb{R}$ quasiciągła ze względu na pierwszą zmienną oraz ciągła ze względu na drugą, ma własność Namioki, tzn. istnieje zbiór $A$ gęsty w $X$ i typu $G_{\delta}$ taki, że $f$ jest ciągła w każdym punkcie zbioru $A \times Y$. W [59] Mykhaylyuk pokazał, że produkt dowolnej rodziny zwartych przestrzeni Kempistego jest także przestrzenią Kempistego. Tematyka ta jest kontynuowana np. w pracy [57].

\section{Podziękowania}

Dziękujemy Archiwum Matematyków Polskich przy bibliotece IMPAN w Warszawie za zdjęcia 4 (ZF238), 10 (ZF410) i 12 (ZF408) oraz za 
zgodę na ich opublikowanie, Archiwum Akt Nowych za odpłatne przesłanie 60 stron dokumentów Kempistego [Kf2], Danucie Ciesielskiej z Warszawy za przesłanie dokumentów z Archiwum UJ oraz skanów prac [K9], [K16], [K41], Walerianowi Piotrowskiemu z Warszawy za skany życiorysu i wykazu publikacji Marii Kempisty z Archiwum Uniwersytetu Warszawskiego [Kf15], Bibliotece Uniwersytetu Mikołaja Kopernika w Toruniu za zdjęcia 5 i 6 (ze zbiorów Sekcji Dokumentów Życia Społecznego Biblioteki Uniwersyteckiej, sygn. F-2470) oraz za zgodę na ich opublikowanie, Bibliotece Głównej AGH za skan pracy [K15] przesłany w grudniu 2016 roku, Krzysztofowi Maślance z Warszawy za informację o zdjęciach 7 i 8 dostępnych w domenie publicznej oraz Oleksandrovi Maslyuchence za udostępnienie pracy habilitacyjnej ojca [54]. Dziękujemy także Romanowi Dudzie za możliwość skorzystania z niepublikowanej jeszcze pracy [Kf10].

\section{Spis publikacji Stefana Kempistego ${ }^{16}$}

\subsection{Spis książek i monografii}

[Ks1] Rachunek różniczkowy i calkowy. Cz. 1. Liczby rzeczywiste. Ciagi i szeregi, Wydawnictwa Koła Matematyczno-Fizycznego Studentów Uniwersytetu St. Batorego, Zakład Litogr. Ch. Łaskow i Syn, Wilno 1931, $\mathrm{v}+346$ stron.

[Ks2] Rachunek różniczkowy i catkowy. Cz. 2. Pochodne i różniczki, szeregi potegowe, calki nieoznaczone i oznaczone, zastosowanie geometryczne, Wydawnictwa Koła Matematyczno-Fizycznego Studentów Uniwersytetu St. Batorego, Zakład Litograficzny Ch. Łaskow i Syn, Wilno 1931, 398 stron.

[Ks3] Rachunek różniczkowy $i$ całkowy. Cz. 3, Funkcje dwu $i$ wielu zmiennych, funkcje uwiktane, Jacobiany, Wydawnictwa Koła Matematyczno-Fizycznego Studentów Uniwersytetu St. Batorego, Zakład Litograficzny Ch. Łaskow i Syn, Wilno 1931, 212 stron.

[Ks4]* Fonctions d'intervalle non-additives, Actualities Scientifiquest Industrielle 824, Ensembles et Fonctions. III. Hermann \& Cie, Paris 1939, 62 strony. JFM 65.1175.01, MR 0001271, Zbl 0026.39101, Bibliothèque National de France.

\footnotetext{
${ }^{16}$ Prace bądź książki oznaczone gwiazdką *, w tej i dalszych częściach bibliografii, są swobodnie dostępne w internecie. Skróty poniżej: JFM = Jahrbuch über die Fortschritte der Mathematik, MR = Mathematical Reviews, Zbl = Zentralblatt für Mathematik.
} 
[Ks5] Równania różniczkowe, Koło Matematyczno-Fizyczne Studentów USB, skrypt ${ }^{17}$.

\subsection{Spis prac naukowych}

[K1] O układach i permutacjach wielościanowych, „Wektor” 5 (1915/6), z. 9-10, 193-198.

[K2] Podstawy ptaskiej gieometrji opisowej, „Wektor” 6 (1916/7), z. 2, 89104.

[K3] Z Zasada indukcji matematycznej a postulat Dedekinda, „Wektor” 6 (1918), z. 3-4, 209-214.

[K4] ${ }^{*}$ O zasadach formalnej teorji liczb naturalnych, „Wiadomości Matematyczne" 24 (1920), 187-196.

$[\mathrm{K} 5]^{*}$ Sur les séries itérées des fonctions continues, „Fundamenta Mathematicae" 2 (1921), 64-73. JFM 48.0276.04.

[K6] $]^{*}$ Sur l'approximation des fonctions de première classe, „Fundamenta Mathematicae" 2 (1921), 131-135. JFM 48.0276.05.

$[\mathrm{K} 7]^{*}$ Sur les trois classifications des fonctions représentables analytiquement, „Annales de la Société Polonaise de Mathématique” 1 (1922), 72-73. JFM 48.1204.01.

$[\mathrm{K} 8]^{*}$ O trzech klasyfikacjach funkcji przedstawialnych analitycznie, Dodatek do Roczników Polskiego Towarzystwa Matematycznego (= Annales de la Société Polonaise de Mathématique. Supplement) 1 (1922), 41-49. JFM 48.0277.02.

[K9] O aproksymatywnej ciagłości funkcyj pochodnych, Prace Towarzystwa Przyjaciół Nauk w Wilnie. Wydział Nauk Matematycznych i Przyrodniczych (= Travaux de la Société des Sciences et des Lettres de Wilno/Classe des Sciences Mathématiques et Naturelles oraz Bulletin du Séminaire de Mathématiques de l'Université de Wilno) 1 (1923), $17-28$.

$[\mathrm{K} 10]^{*}$ Sur les fonctions approximativement discontinues, „Fundamenta Mathematicae" 6 (1924), 6-8. JFM 50.0186.03.

[K11]* Sur les fonctions dérivées bornées, „Annales de la Société Polonaise de Mathématique" 3 (1924), 88-91 (1925). JFM 51.0207.05.

\footnotetext{
${ }^{17} \mathrm{Nie}$ widzieliśmy tej pozycji, ale umieszczamy ten skrypt na liście, gdyż taką informację znaleźliśmy w pracy Szałajko [77, str. 92].
} 
$[\mathrm{K} 12]^{*}$ Sur les limites approximatives (asymptotiques), „Comptes Rendus Hebdomadaires des Seances de l'Académie des Sciences" 180 (1925), 642-645. JFM 51.0201.08.

$[\mathrm{K} 13]^{*}$ Un nouveau procédé d'intégration de fonctions mesurables non sommables, "Comptes Rendus Hebdomadaires des Seances de l'Académie des Sciences" 180 (1925), 812-815. JFM 51.0202.01.

[K14]* Sur l'intégration des fonctions mesurables, „Comptes Rendus Hebdomadaires des Seances de l'Académie des Sciences" 180 (1925), 10111014. JFM 51.0202.02.

[K15] O funkcjach pochodnych ograniczonych, Dodatek do Roczników Polskiego Towarzystwa Matematycznego (=Annales de la Société Polonaise de Mathématique. Supplement) 2 (1925), 1-27, JFM 51.0215.07.

[K16] Sur les dérivées de la fonction d'ensemble, „Comptes Rendus Hebdomadaires des Seances de l'Académie des Sciences" 182 (1926), 12051207. JFM 52.0252.03.

[K17]* O funkcjach Baire'a (Sur les fonctions de M. Baire), Sprawozdania z Posiedzeń Towarzystwa Naukowego Warszawskiego, Wydział III Nauk Mat. i Przyrodniczych (= C. R. Soc. Sci. Varsovie, CI. III) 19 (1926), z. 1-5, 35-38 (po francusku). JFM 57.1388.11.

$[\mathrm{K} 18]^{*}$ Intégration de la dérive régulière, „Comptes Rendus Hebdomadaires des Seances de l'Académie des Sciences" 184 (1927), 69-71. JFM 53.0230 .02 .

[K19]* Sur l'intégrale (A) de M. Denjoy, „Comptes Rendus Hebdomadaires des Seances de l'Académie des Sciences" 185 (1927), 749-751. JFM 53.0228 .01 .

[K20]* O calkach funkcji przedziatu (Sur les intégrales d'une fonction d'intervalle), [w:] Ksiega Pamiatkowa Pierwszego Polskiego Zjazdu Matematycznego (Lwów 7-10 IX 1927), Kraków 1929, 93-97 (po francusku); przedrukowane przez PTM, Warszawa 2009.

[K21]* O pochodnych funkcji przedziału (Sur les dérivées d'une fonction d'intervalle), [w:] Ksiega Pamiatkowa Pierwszego Polskiego Zjazdu Matematycznego (Lwów 7-10 IX 1927), Kraków 1929, 98-101 (po francusku); przedrukowane przez PTM, Warszawa 2009.

$[\mathrm{K} 22]^{*}$ Sur les fonctions semi-continues par rapport à chacune de deux variables, „Fundamenta Mathematicae” 14 (1929), 237-241. JFM 55.0145.05. 
$[\mathrm{K} 23]^{*}$ L'intégration des fonctions sommables, „Annales de la Société Polonaise de Mathématique" 8 (1929), 226-243 (1930). JFM 56.0922.05.

[K24] Catkowanie w przedziale nieskończonym, [w:] Sprawozdanie z I Kongresu Matematyków Krajów Stowiańskich (Comptes-Rendus du I Congrès des Mathématiciens des Pays Slaves, Warszawa, 1929), Książnica Atlas, Warszawa 1930, 229-232. JFM 56.0925.05.

[K25] Sur les fonctions ponctuellement discontinues, [w:] Sprawozdanie z I Kongresu Matematyków Krajów Stowiańskich (Comptes-Rendus du I Congrès des Mathématiciens des Pays Slaves, Warszawa, 1929), Książnica Atlas, Warszawa 1930, 275-278 (po francusku). JFM 56.0918 .02 .

[K26]* Sur l'intégrale (A) de M. Denjoy, „Comptes Rendus Hebdomadaires des Seances de l'Académie des Sciences" 192 (1931), 1186-1189. JFM 57.0296.01, Zbl 0002.02004.

[K27]* L'intégration des fonctions sommables, „Annales de la Société Polonaise de Mathématique" 10 (1931), 1-11 (1932). JFM 58.1059.02, Zbl 0006.1951 .

$[\mathrm{K} 28]^{*}$ Sur les dérivées des fonctions des systèmes simples d'intervalles, Bulletin de la Société Mathematique de France 60 (1932), 106-126. JFM 58.0256.01, MR 1504985, Zbl 0005.05803.

[K29]* Sur les fonctions quasicontinues, „Fundamenta Mathematicae” 19 (1932), 184-197. JFM 58.0246.01, Zbl 0005.19802.

$[\text { K30 }]^{*}$ Sur la totalisation des fonctions de deux variables, „Comptes Rendus Hebdomadaires des Seances de l'Académie des Sciences" 198 (1934), 2060-2062. JFM 60.0215.01, Zbl 0009.20801.

[K31]* The extreme derivates of functions of one and more variables, „The Journal of the London Mathematical Society" 9 (1934), 303-308. JFM 60.0213.02, Zbl 0010.15901.

[K32] Sur les fonctions partiellement continues, „Mathematica (Cluj)” 9 (1935), 93-102. JFM 61.1104.03, Zbl 0013.34801.

[K33] Sur les operations de la topologie générale, „Mathematica (Cluj)” 10 (1935), 137-156. JFM 61.1099.01, Zbl 0011.17903.

[K34]* Sur les bornés des fonctions réelles, „Bulletin de la Société Mathematique de France" 63 (1935), 91-120. JFM 61.1103.03, MR 1505032, Zbl 0012.25101. 
$[\text { K35 }]^{*}$ Sur l'aire de la surface $z=f(x, y)$, „Comptes Rendus Hebdomadaires des Seances de l'Académie des Sciences" 202 (1936), 1138-1140. JFM 62.0259.02, Zbl 0013.29901.

[K36]* Intégrale Denjoy-Stieltjes d'une function de deux variables, „Comptes Rendus Hebdomadaires des Seances de l'Académie des Sciences" 202 (1936), 1241-1244. JFM 62.0253.02, Zbl 0013.29902.

$[\text { K37 }]^{*}$ Sur les fonctions absolument continues d'intervalle, „Fundamenta Mathematicae" 27 (1936), 10-37. JFM 62.0248.04, Zbl 0015.10504.

[K38]* Sur la méthode triangulaire du calcul de l'aire d'une surface courbe, „Bulletin de la Société Mathématique de France” 64 (1936), 119-132. JFM 62.0259.03, MR 1505052, Zbl 0015.01003.

$[\mathrm{K} 39]^{*}$ Sur les fonctions absolument semi-continues, „Fundamenta Mathematicae" 30 (1938), 104-127. JFM 64.0200.01, Zbl 0018.11401; Errata, „Fundamenta Mathematicae” 30 (1938), 128. JFM 64.0200.02.

[K40] Zastosowanie funkcji trójkata do teorji pola powierzchni krzywej. Applications de fonctions de triangle à la théorie de l'aire d'une surface courbe, Prace Towarzystwa Przyjaciół Nauk w Wilnie. Wydział Nauk Matematycznych i Przyrodniczych (= Travaux de la Société des Sciences et des Lettres de Wilno/Classe des Sciences Mathématiques et Naturelles) 12 (1937), 212-219 (1938) (po francusku) oraz Bulletin du Séminaire de Mathématiques de l'Université de Wilno 1 (1938), 5-12. JFM 64.0707.03, Zbl 0019.00905.

[K41] O funkcjach o wahaniu skończonem w sensie Tonelliego. Sur les fonctions à variation borné au sens de Tonelli, Prace Towarzystwa Przyjaciół Nauk w Wilnie. Wydział Nauk Matematycznych i Przyrodniczych (= Travaux de la Société des Sciences et des Lettres de Wilno/Classe des Sciences Mathématiques et Naturelles) 13 (1938), 213-221 (1939) (po francusku) oraz Bulletin du Séminaire de Mathématiques de l'Université de Wilno 2 (1939), 13-21. JFM 64.0707.03, MR 0000046, Zbl 0021.11501.

$[\mathrm{K} 42]^{*}$ Sur l'aire des surfaces courbes continues, „Fundamenta Mathematicae" 33 (1945), 34-41 (wpłynęła 9 grudnia 1938). JFM 65.0203.02, MR 0001280 (1,209b), Zbl 0061.11507.

Stefan Kempisty brał czynny udział w pracach Polskiego Towarzystwa Matematycznego w Oddziale w Wilnie, który powstał w 1925 roku. Wygłosił następujące odczyty w Towarzystwie w Wilnie:

[23 I 1933] Les opérations monotones sur les ensembles (praca [K33]). 
[29 I 1934] Sur les dérivées extrémes des functions d'une et de plusieurs variables (praca [K31]).

[30 IV 1934] Les fonctions absolument continues sur un ensemble (praca [K30]).

[3 III 1937] Fonctions de triangle et leurs applications au calcul de l'aire d'une surface (praca [K41]).

[28 XI 1938] Sur l'aire des surfaces continues.

Ponadto Kempisty w latach 1927-1939 napisał 115 recenzji dla Jahrbuch über die Fortschritte der Mathematik (JFM) ${ }^{18}$, data dostępu 07.09.2017.

\section{Informacje o Stefanie Kempistym, jego żonie i córce.}

[Kf1] Stefan Jan Kempisty, Archiwum Uniwersytetu Jagiellońskiego, WF II 504, w tym: własnoręczny życiorys z 4 VII 1918; ocena pracy doktorskiej napisana przez S. Zarembę z 1918 roku (5 stron); protokoły z egzaminów do doktoratu z 11 VII 1919 (filozofia) i 15 VII 1919 (matematyka i geofizyka); dyplom doktorski z 1919 roku.

[Kf2] Stefan Jan Kempisty, materiały w Archiwum Akt Nowych w Warszawie, MWRiOP, Del. Rz., sygn. 202/I-51, 202/III-196, MWRiOP, sygn. 24. Także MWRiOP, sygn. 3298, 60 stron w tym: CV i spis prac z 12 X 1919; własnoręczny życiorys z 2 XII 1924 roku (1 strona); życiorys z 1935 roku (2 strony), spis prac (2 strony) i referat Komisji do sprawy uzwyczajnienia Prof. Dr. Stefana Kempistego (5 stron) z 1935 roku; odpis nominacji na profesora zwyczajnego z 14 IX 1937 roku.

[Kf3] Stefan Jan Kempisty, Centralne Archiwum Litwy, Wydział Matematyczno-Przyrodniczy. Rękopis 175. B_6.58. W książce Przeniosło (2011): Litewskie Centralne Archiwum Państwowe w Wilnie: USB fond 175, ap. 6VIIB, 200, 209, b. 239, k. 10, 18-21, 26, 29, 43, 45, 46, 49-51, 61; ap. 14, b. 154, k. 2, 2v, 4, 5, 10, 18, 19. Sprawozdanie z podróży naukowej Prof. Dr. Stefana Kempistego dla MWRiOP, Wilno 29 kwietnia 1936, 1 strona.

[Kf4] Stefan Jan Kempisty, [w:] S. Łoza, Czy wiesz kto to jest?, Wydawnictwo Głównej Księgarni Wojskowej, Warszawa 1938, 332.

[Kf5]* D. Ciesielska i L. Maligranda, Alfred Rosenblatt (1880-1947), „Wiadomości Matematyczne" 50 (2014), nr 2, 221-259 [Kempisty, str. 226]. MR 3309176, Zbl 1320.01024.

\footnotetext{
${ }^{18}$ Listę recenzji daje zapytanie rv:Kempisty, S.; Prof na stronie https://zbmath.org/.
} 
[Kf6] ${ }^{*}$ S. Domoradzki i Z. Pawlikowska-Brożek, Uniwersytet Wileński, „Wiadomości Matematyczne" 35 (1999), 125-139 [Kempisty, str. 130-136, 139], [błędna informacja, że promotorem doktoratu był Stanisław Zaremba].

[Kf7] Drugi Zjazd Matematyków Polskich w Wilnie, „Parametr” 2 (1932), z. 6-7, 194-198 [Kempisty, str. 194-196 + zdjęcie, na którym jest Kempisty str. 195].

$[\mathrm{Kf8}]^{*}$ R. Duda, O stratach osobowych matematyki polskiej zwiazanych z II wojna światowa, „Aniquitates Mathematicae” 3 (2009), 137-169 [Kempisty, str. 143 i 160-161, gdzie jest spis zawierający 28 prac Kempistego]. MR 2808797

[Kf9] R. Duda, Kempisty, Stefan Jan (1892-1940), [w:] Matematycy XIX i XX wieku zwiazani z Polska, Wydawnictwo Uniwersytetu Wrocławskiego, Wrocław 2012, 207-208.

[Kf10] R. Duda, Okupacja Wilna i śmierć Kempistego, Antiquitates Mathematicae, w druku.

[Kf11] R.S. Ingarden i S. Kalembka, O fizyce $i$ innych naukach ścistych $w$ Wilnie, Toruniu $i$ gdzie indziej. Rozmowy z profesorami Kazimierzem Antonowiczem, Wilhelmina Iwanowska, Leonem Jeśmanowiczem, Jerzym Rayskim, Wydawnictwo UMK, Toruń 2005, 157 stron [Kempisty, str. 55, 65, 66, 73].

[Kf12] L. Jeśmanowicz, Wspomnienia o matematykach wileńskich, „Wiadomości Matematyczne" (2) 12 (1971), nr 2, 309-319 [Kempisty, str. 309314]. MR 0453453 (56 \#11716).

[Kf13] I. Jóźwik i M. Terepeta, Prace Stefana Kempistego z teorii funkcji rzeczywistych, lipiec 2016, maszynopis 13 stron.

[Kf14] S. Kalbarczyk, Kempisty Stefan Jan (1892-1940), [w:] Polscy pracownicy nauki - ofiary zbrodni sowieckich w latach II wojny światowej, Wydawnictwo NERITON, Warszawa 2001, 110-111.

[Kf15] Maria Kempisty, Archiwum Uniwersytetu Warszawskiego, w tym: teczka pracownicza nr 6708, teczka przewodu doktorskiego nr IFZ-53150 oraz teczka przewodu habilitacyjnego nr WF-534-262.

[Kf16] S. Kolankowski, S. Domoradzki i Z. Pawlikowska-Brożek, Kempisty Stefan Jan (1892-1940), [w:] Stownik Biograficzny Matematyków Polskich, pod red. S. Domoradzkiego, Z. Pawlikowskiej-Brożek i D. Węglowskiej, Tarnobrzeg 2003, 99-100. 
$[\text { Kf17 }]^{*}$ L. Maligranda, Józef Marcinkiewicz (1910-1940) - on the centenary of his birth, Banach Center Publications 95 (2011), 133-234 [Kempisty, str. 135, 139, 142, 210; cytuje [K39]. Zdjęcia z Kempistym na stronach 139-zdjęcie 6 i 142-zdjęcie 9]. MR 2918095, Zbl 1239.01097.

[Kf18] Nekrolog: Eugenia Szczeniowska z Pogorzelskich I voto Kempisty, „Życie Warszawy” R. 40, nr 4 (12206) A z 6 stycznia 1983, s. 8.

[Kf19] Z. Opial, Kempisty Stefan Jan (1892-1940), [w:] Polski Stownik Biograficzny, Wrocław-Warszawa-Kraków 1966-1967, 338-339 [błędna informacja, że promotorem doktoratu był Stanisław Zaremba].

[Kf20]* V. Paulauskas, Mathematics at the Stefan Batory University in Vilnius (1919-1939), „Litovsk. Mat. Sb.” 20 (1980), no. 3, 13-17; tłumaczenie angielskie: „Lithuanian Math. J.” 20 (1980), no. 3, 190-193 (1981) [Kempisty, str. 190-192]. MR 0598954 (83i:01083).

[Kf21] J. Piłatowicz, Szczeniowski Szczepan Eugeniusz (1898-1979), [w:] Polski Stownik Biograficzny, Warszawa-Kraków 2010-2011, 261-265 [Kempisty, str. 264].

[Kf22] M. Przeniosło, Kempisty Stefan Jan, [w:] Matematycy Polscy w Dwudziestoleciu Międzywojennym, Wyd. Uniwersytetu HumanistycznoPrzyrodniczego Jana Kochanowskiego, Kielce 2011, 386.

[Kf23] B. Rydzewski, Dr. Stefan Jan Kempisty, [w:] Wydział MatematycznoPrzyrodniczy Uniwersytetu Stefana Batorego w latach 1919-1929, Wilno 1931, 90-91.

[Kf24] Z. Walczy, Kempisty Stefan Jan (1892-19490), [w:] Wychowankowie Uniwersytetu Jagiellońskiego - Ofiary II wojny światowej (1939-1945). Biogramy, Tom I, Stowarzyszenie Absolwentów Uniwersytetu Jagiellońskiego, Kraków 1995, s. 73 [błędna informacja, że promotorem doktoratu był Stanisław Zaremba].

[Kf25] W. Wójcik, Kempisty Stefan Jan, [w:] Polski wkład w przyrodoznawstwo i technike. Stownik polskich i zwiazanych z Polska odkrywców, wynalazców oraz pionierów nauk matematyczno-przyrodniczych $i$ techniki (red. B. Orłowski), Tom II H- - , Instytut Historii Nauki im. L. i A. Birkenmajerów PAN, Warszawa 2015, 181-183 [błędna informacja, że promotorem doktoratu był Stanisław Zaremba].

[Kf26] B. Żongołłowicz, Dzienniki 1930-1939, Warszawa 2004, xxxix +776 stron [Kempisty, str. 102, 671]. 


\section{Cytowane prace bądź książki oraz informacje}

[1] C. R. Adams and J. A. Clarkson, Properties of functions $f(x, y)$ of bounded variation, "Transactions of the American Mathematical Society" 36 (1934), no. 4, 711-740 [Kempisty, str. 714-715, cytuja [K22]]. JFM 60.0201.04.

$[2]^{*}$ A. Alexiewicz et W. Orlicz, Sur la continuité et la classification de Baire des fonctions abstraites, „Fundamenta Mathematicae” 35 (1948), 105-126; przedruk [w:] Władysław Orlicz, Collected Papers, Part I, PWN, Warszawa 1988, 535-556 [Kempisty, str. 115, 119, 126; cytują [K29]]. MR 0027445 (10,307e), Zbl 0031.21903.

[3] L. I. Alpert and L. V. Toralballa, An elementary definition of surface area in $E^{n+1}$ for smooth surfaces, "Pacific Journal of Mathematics" 40 (1972), no. 2, 261-268 [Kempisty, str. 261, 268; cytują [K38]]. MR 0306425 (46 \#5551), Zbl 0237.26003.

[4] R. Baire, Sur les fonctions de variables réelles, „Annali di Matematica Pura ed Applicata" (3) 3 (1899), 1-123. JFM 30.0359.01.

[5] R. Baire, Lecons sur les fonctions discontinues, Gauthier-Villars, Paris 1905, viii+127 str. JFM 36.0438.01.

[6] J. J. Benedetto, Spectral Synthesis, Teubner, Stuttgart 1975, 278 str. [Kempisty, str. 231, 233, 274]. MR 0622037 (58 \#29850a).

[7] J. J. Benedetto and W. Czaja, Integration and Modern Analysis, Birkhäuser, Boston-Basel-Berlin 2010, xiii+573 str. [Kempisty, str 103, cytuje [Ks4]]. MR 2559803 (2010k:28001).

[8] W. W. Bledsoe, Neighborly functions, „Proceedings of the American Mathematical Society" 3 (1952), no. 1, 114-115. MR 0045791 $(13,634 d)$.

[9] A. M. Bruckner, Differentiation of Real Functions, Lecture Notes in Mathematics 659, Springer, Berlin 1978 [Kempisty, str. 179; cytuje [K29]]. MR 0507448 (80h:26002).

[10] A. M. Bruckner, J. B. Bruckner and B. S. Thomson, Real Analysis, Prentice-Hall, New Jersey 1997, xiv+ 713 str.Zbl 0872.26001.

[11] A. M. Bruckner and B. S. Thomson, Real variable contributions of G.C. Young and W.H. Young, „Expositiones Mathematicae” 19 (2001), no. 4, 337-358 [Kempisty, str. 346, 356; cytują [K10]]. MR 1876254 (2003e:01030). 
[12] P. S. Bullen, Non-absolute integrals: a survey, „Real Analysis Exchange" 5 (1979/80), no. 2, 195-259 [Kempisty, str. 204, 217, 218; cytuje [Ks4], [K13], [K19], [K26], [K30], [K36], [K37]].Zbl 0438.26004.

[13] $]^{*}$ P. S. Bullen, Non-absolute integrals in the twentieth century, Toronto 2000, artykuł 27- stronicowy dostępny w: https://www.emis.de/proceedings/Toronto2000/papers/bullen.pdf, data dostępu 07.09.2017 [Kempisty, str. 6, 7, 21; cytuje [K30], [K36]].

[14] C. Caratheodory, Vorlesungen über reelle Funktionen, Teubner, Leipzig und Berlin 1918, x+704 str. JFM 46.0376.12.

[15] R. Cazacu and J. D. Lawson, Quasicontinuous functions, domains, and extended calculus, "Applied General Topology” 8 (2007), no. 1, 1-33 [Kempisty, str. 32; cytują [K29]]. MR 2335278 (2008d:54009)

[16] V. G. Čelidze i A. G. Džvaršěšvili, Teoria całki Denjoy i pewne jej zastosowania, Wyd. Uniwersytetu Tbiliskiego, Tbilisi 1978 (po rosyjsku) [Kempisty, str. 4, 359; cytują [K37], [K39]]; angielskie tłumaczenie: V. G. Čelidze, A. G. Džvaršeǐšvili, The Theory of the Denjoy Integral and Some Applications, World Scientific, Singapore 1989 [Kempisty, str. viii, 93, 97, 100, 132, 301, 320; cytują [K37], [K39]]. MR 1036270 (90k:26013)

[17] L. Cesari, Surface Area, Princeton University Press, Princeton 1956, x+595 str. [Kempisty, str. 74, 79, 411, 584; cytuje [[Ks4], [K16], [K23], [K30], [K35], [K37], [K38], [K40]]. MR $0074500(17,596 \mathrm{~b})$

$[18]^{*}$ L. Cesari, Quasi-additive set functions and the concept of integral over a variety, "Transactions of the American Mathematical Society” 102 (1962), 94-113 [Kempisty, str. 95, 113; cytuje [Ks4]]. MR 0142723 (26 \#292).

[19] U. B. Darji, M. J. Evans, Ch. Freiling and R.J. O'Malley, Fine properties of Baire one functions, „Fundamenta Mathematicae” 105 (1998), 177-188 [Kempisty, str. 177; cytuje [K29]]. MR 1606523 (98k:26007).

$[20]^{*}$ A. Denjoy, Sur les fonctions dérivées sommables, „Bulletin de la Société Mathematique de France” 43 (1915), 161-248. JFM 45.1286.01.

[21]* S. Dudik, The Kempisty Co. Stawomir Dudik - Historia, Naprawa maszyn do szycia, 2015. Data dostępu 2017-09-30.

[22]* S. Enomoto, Notes sur l'intégration. I. Quelques propriétés des fonctions d'intervalle, „Proceedings of the Japan Academy” 30 (1954), 176179 (po francusku) [Kempisty, str. 176, 179; cytuje [Ks4], [K37]]. MR 0064851 
[23] M. Fréchet, Sur une définition intrinsèque de l'aire d'une surface courbe comme limite d'aires polyédrales inscrites, „Annali Scuola Normale Superiore de Pisa. Scienze. Fisiche e Matematiche" (2) 8 (1939), 285-300 [Kempisty, str. 289, 300; cytuje [K38]]. JFM 65.0203.01.

[24] S. Gandon and Y. Perrin, Le problème de la définition de l'aire d'une surface gauche: Peano et Lebesgue, „Archive for History of Exact Sciences" 63 (2009), no. 6, 665-704 [Kempisty, str. 677, 703; cytuja [K38]]. MR 2550748 (2010j:01008).

[25] G. Gibson and T. Natkaniec, Darboux like functions, „Real Analysis Exchange" 22 (1996/97), no. 2, 492-533 [Kempisty, str. 506, 531; cytują [K29]]. MR 1460971 (98h:26004).

[26] Z. Grande and T. Natkaniec, On some topologies of O'Malley's type on the plane, „Real Analysis Exchange” 18 (1992/93), no. 1, 241-248 [Kempisty, str. 241; cytuje [K29]]. MR 1205518 (94c:54005).

[27] Z. Grande, Kempisty's theorem for the integral product quasicontinuity, "Colloquium Mathematicum" 106 (2006), no. 2, 257-264 [Kempisty, str. 257, 259, 260, 264; cytuje [K29]]. MR 2283813 (2007m:26006).

[28] H. Greniewski and M. Kempisty, Cybernetyka z lotu ptaka, Książka i Wiedza, Warszawa 1963, 142 str.; przekład niemiecki Kybernetische Systemtheorie ohne Mathematik, Dietz, Berlin 1966, 141 str.

[29] H. Hahn, Über Funktionen mehrerer Ver änderlicher, die nach jeder einzelnen Veränderlichen stetig sind, "Mathematische Zeitschrift” 4 (1919), 306-313. JFM 47.0244.01.

[30] H. Hahn, Theorie der reellen Funktionen. Erster Band, Springer, Berlin 1921, vii+600 str. JFM 48.0261.09.

[31] K. P. Hart and J. Nagata, Encyclopedia of General Topology, Elsevier, Amsterdam 2004 [Kempisty, str. 129, cytują [K29]]. MR 2049453 (2005d:54001).

[32] O. Haupt, Zur Differentiation additiver Funktionen, „Mathematische Nachrichten" 8 (1952), 93-97 [Kempisty, str. 93; cytuje [Ks4]]. MR 0052487.

[33] R. Henstock, Interval Functions and their Integrals, Ph. D. Thesis, Birkbeck College, London, December 1948, 128 stron; opublikowana 23 lutego 2017 roku w arXiv: 1702.08486 [Kempisty, str. 3, 4, 7, 60, 79, 90, 92, 96-102, 127, 128; cytuje [Ks4], [K37]]. 
[34] R. Henstock, Integration, variation and differentiation in division spaces, „Proceedings of the Royal Irish Academy” 78 (1978), 69-85 [Kempisty, str. 73, cytuje [Ks4], [K37]]. MR 0513301.

[35] Ľ. Hóla, Functional characterizations of p-spaces, „Central Europen Journal of Mathematics" 11(12) (2013), 2197-2202 [Kempisty, str. 2198, cytuje [K29]]. MR 3111716.

[36] Jubileusz 65-lecia działalności naukowej, pedagogicznej i społecznej profesora Samuela Dicksteina, Warszawa, 3. X. 1937, III Polski Zjazd Matematyczny, Staraniem Komitetu Jubileuszowego, Warszawa 1938, 50 stron+zdjęcie.

[37]* M. Kempisty-Goettig, Les systèmes relativement isolés. Une méthode dynamique graphique, „Cahiers du Séminaire d'Économétrie” 6 (1962), 161-164. http://www.jstor.org/stable/20075386.

$[38]^{*}$ M. Kempisty, Binarne sprzężenia zwrotne, „Studia Logica” 14 (1963), $255-338$.

[39] M. Kempisty, 0-1 Modele Cybernetyczne, Państwowe Wydawnictwo Naukowe, Warszawa 1963, 120 str.

[40] M. Kempisty, Pamięć skojarzeniowa: model cybernetyczny, Państwowe Wydawnictwo Naukowe, Warszawa 1968, 264 str.

[41]* M. Kempisty, Introduction to storage theory, „Studia Logica” 26 (1970), 73-85. MR 0282737 (43 \#8446).

[42] M. Kempisty, Cybernetyka narzędziem kierownictwa, Towarzystwo Naukowe Organizacji i Kierownictwa, Warszawa 1971 i 1972, 98 str.

[43] M. Kempisty (red.), Mały Słownik Cybernetyczny, Wiedza Powszechna, Warszawa 1973, 533 str.

[44] J. P. Lee and Z. Piotrowski, On Kempisty's generalized continuity, „Rendiconti del Circolo Matematico di Palermo”. Second Series 34 (1985), no. 3, 380-386 (1986) [Kempisty, str. 380, 386; cytują [K29]]. MR 0848116 (87h:54024).

[45] J. P. Lee and Z. Piotrowski, Another note on Kempisty's generalized continuity, „International Journal of Mathematics and Mathematical Sciences" 11 (1988), no. 4, 657-663 [Kempisty, str. 657-659, 663; cytują [K29]]. MR 0959445 (89i:54018). 
[46] $]^{*}$ N. Levine, Semi-open sets and semi-continuity in topological spaces, „The American Mathematical Monthly" 70 (1963), 36-43. MR 0166752 (29 \#4025).

[47] J. Lipiński and T. Šalát, On the points of quasicontinuity and cliquishness of functions, „Czechoslovak Mathematical Journal” 21 (1971) no. 3, 484-489 [Kempisty, str. 484, cytuje [K29]]. MR 0287517 (44 \#4721).

[48]* A. J. B. Lopes-Pinto and D. A. Mendes, On the semi-continuity in product spaces, preprint of 8 pages submitted on 23 January 2002 at arXiv:math/0201222 [Kempisty, str. 1, 8; cytują [K22]].

[49] A. Maliszewski, Averages of quasi-continuous functions, „Mathematica Bohemica", 124 (1999), no. 1, 29-34 [Kempisty, str. 29; cytuje [K29]]. MR 1687429 (2000d:26005).

[50]* S. Marcus, Sur les dérivées partielles mixtes, „Comptes Rendus Hebdomadaires des Seances de l'Académie des Sciences" 246 (1958), 522-524 [Kempisty, str. 524; cytuje [K29]]. MR 0095909 (20 \#2407).

[51]* S. Marcus, Sur les fonctions dérivées, intégrables au sens de Riemann et sur les dérivées partielles mixtes, „Proceedings of the American Mathematical Society" 9 (1958), 973-978 [Kempisty, str. 973, 974, 977, 978; cytuje [K29]]. MR 0103243 (21 \#2024).

[52]* S. Marcus, Sur les fonctions quasicontinues au sens de S. Kempisty, "Colloquium Mathematicum" 8 (1961), 47-53 [Kempisty, str. 47, 50, 51; cytuje [K29]]. MR 0125915 (23 \#A3212).

[53]* N. F. G. Martin, Quasi-continuous functions on product spaces, „Duke Mathematical Journal" 28 (1961), 39-44 [Kempisty, str. 39, 43; cytuje [K29]]. MR 0147906 (26 \#5419).

[54] V. K. Maslyuchenko, Separately continuous mappings and Köthe spaces, Dys. Doktora Fiz.-Mat. Nauk. Chernivtsi 1999 (po ukraińsku).

[55]* S. Mazurkiewicz, Sur les fonctions de classe 1, „Fundamenta Mathematicae" 2 (1921), 28-36. JFM 48.0276.02.

[56] F. Medvedev, Scenes from the history of real functions, Birkhäuser Verlag, Basel 1991, 265 str. [Kempisty, str. 167, 246, 262; błędna data śmierci na stronie 262; cytuje [K5]]. MR 1149127 (93d:26001).

[57] A. Mirmostafaee, Topological games and strong quasi-continuity, „Banach Journal of Mathematical Analysis" 5 (2011), no. 2, 131-137 [Kempisty, str. 131, cytuje [K29]]. MR 2818681 (2012g:54032). 
[58]* M. Morayne, Algebras of Borel measurable functions, „Fundamenta Mathematicae" 141 (1992), no. 3, 229-242 [Kempisty, str. 229, 230, 242; cytuje [K5]; pozytywnie rozwiązuje problem Kempistego]. MR 1199236 (93j:26003).

[59] V. V. Mykhaylyuk, The Namioka property of KC-functions and Kempisty spaces, ,Topology and its Applications” 153 (2006), no. 14, 24552461 [Kempisty, str. 2455-2456, 2458-2461; cytuje [K29]]. MR 2243724 (2007f:54018).

[60] T. Neubrunn, A generalized continuity and product spaces, „Mathematica Slovaca" 26 (1976), no. 2, 97-99 [Kempisty, str. 97, 99; cytuje [K29]]. MR 0436064 (55 \#9015).

[61] T. Neubrunn, Quasi-continuity, „Real Analysis Exchange”, (1988-89), vol 14, no. 2, 259-306 [Kempisty, str. 259, 260, 275, 278, 281, 283; cytuje [K29]]. MR 0995972 (90f:54025).

[62] A. Neubrunnova, On certain generalizations of the notion of continuity, „Matematicky Časopis Slovenskej Akadémie Vied” 23 (1973), 374-380 [Kempisty, str. 374, 379; cytuje [K29]]. MR 0339051 (49 \#3814).

[63] E. Omasta, Approximations by differences of lower semicontinuous functions, "Tatra Mountains Mathematical Publications" 62 (2015), 183-190 [Kempisty, str. 183, 187, 190; cytuje [K6]]. MR 3384708, doi: 10.1515/tmmp-2015-0015.

[64] K. Ostaszewski, Variational equivalence and generalized absolute continuity, „Real Analysis Exchange” 10 (1984/85), no. 1, 220-229 [Kempisty, str. 220, 226, 227, 229; cytuje [K37]]. MR 0795620 (86h:26008).

[65] K. Ostaszewski, Nonabsolute integration in the plane, „Real Analysis Exchange" (1985/86), vol. 11, no. 1, 30-39 [Kempisty, str. 33,34; cytuje [Ks4], [K30], [K36], [K37]]. MR 0828477.

$[66]^{*} \mathrm{~K}$. Ostaszewski, Henstock integration in the plane, „Memoirs of the American Mathematical Society" 63 (1986), no. 353, viii + 106 str. [Kempisty, str. iii, iv, 57, 58-59, 62-63, 81, 83-87, 103-104. Rozdział 4 ma tytuł „The integral of Kempisty”; cytuje [Ks4], [K30], [K36], [K37]]. MR 0856159 (87j:26016).

[67] M. Pawłowicz, The Kempisty Company [pdf, data dostępu: 07.09.2017], Grzegorz Bielawski (red. nacz.), Firma 4, (1985) s. 10-11, ISSN 02091607. 
[68] Z. Piotrowski, A survey of results concerning generalized continuity of topological spaces, „Acta Mathematica Universitatis Comenianae” 52/53 (1987), 91-110 (1988) [Kempisty, str. 91, 109, cytuje [K29]]. MR 0989626 (90h:54014).

[69] T. Radó, O polu powierzchni krzywych, „Mathesis Polska” 7 (1932), 1-18. JFM 58.1059.01.

[70] T. Radó, Length and Area, American Mathematical Society, New York 1948 [Kempisty, str. 262, 561, 565; cytuje [Ks4], [K37], [K38], [K40]]. MR $0024511(9,505 \mathrm{~g})$.

[71]* S. Saks, Théorie de L'intégrale, Monografie Matematyczne, Tom II, Fundusz Kultury Narodowej, Warszawa 1933, xii + 290 str. [Kempisty, str. 277; cytuje [K20], [K28]]. JFM 59.0266.03.

[72]* S. Saks, Theory of the Integral, Monografie Matematyczne, Tom VII, Fundusz Kultury Narodowej, Warszawa-Lwów 1937, vi + 347 str. [Kempisty, str. 181, 335; cytuje [K38]]. JFM 63.0183.05.

[73] M. Seweryn-Kuzmanovska and S. Chalamani, Different notions of continuity, „Horizons”, International Scientific Journal, Ser. B, „St. Kliment Ohridski" University-Bitola 1 (2014), 33-43 [Kempisty, str. 33, 42; cytują [K29]].

[74]* W. Sierpiński, Sur les fonctions développables en séries absolument convergentes de fonctions continues, „Fundamenta Mathematicae” 2 (1921), 15-27; przedruk [w:] Oeuvres Choisies, Tom II, PWN, Warszawa 1975, 347-357 [Kempisty, str. 27 i 357; cytuje [K5]]. JFM 48.0276.01.

[75]* W. Sierpiński, Sur une propriété des ensembles ambigus, „Fundamenta Mathematicae" 6 (1924), 1-5; przedruk [w:] Oeuvres Choisies, Tom II, PWN, Warszawa 1975, 544-548 [Kempisty, str. 4, 5 i 547, 548; cytuje [K6], [K7]].

[76] W. Sierpiński, Funkcje Przedstawialne Analitycznie (Wykkady Uniwersyteckie), Lwów-Warszawa-Kraków 1925, i + 104 str. Książka dostępna w: http://hint.org.pl//res/matem/sierpinski_1925.pdf, data dostępu 07.09.2017.

[77] K. Szałajko, Wspomnienia o Kole Matematyczno-Fizycznym studentów Uniwersytetu Jana Kazimierza we Lwowie, „Wiadomości Matematyczne" 26 (1984), 85-96 [Kempisty, str. 92]. 
[78]* T. Świątkowski, Czy tylko przyczynki? Nurt mnogościowy w teorii funkcji rzeczywistych, [w:] Matematyka przełomu XIX i XX wieku. Nurt mnogościowy, Materiały III Ogólnopolskiej Szkoły Historii Matematyki (Jawor 25-29 maj 1988), Redaktor naukowy Jerzy Mioduszewski, Prace Naukowe Uniwersytetu Śląskiego w Katowicach, Uniwersytet Śląski, Katowice 1992, 11-16 [Kempisty, str. 12, 14, 16; cytuje [K6], [K10], [K22], [K29]]. MR 1196951.

$[79]^{*}$ H. P. Thielman, Types of functions, „The American Mathematical Monthly" 60 (1953), no. 3, 156-161. MR 0052495 (14, 628h).

[80] B. S. Thomson, Symmetric Properties of Real Functions, Marcel Dekker, New York 1994, xvi+447 str. [Kempisty, str. 412, cytuje [K29]]. MR 1289417 (95m:26002).

[81] L. V. Toralballa, A geometric theory of surface area. I. Non-parametric surfaces, „Monatshefte für Mathematik” 74 (1970), 462-476 [Kempisty, str. 475; cytuje [K38]]. MR 0280685 (43 \#6404).

$[82]^{*}$ C. T. Tucker, On a theorem concerning Baire functions, „Proceedings of the American Mathematical Society" 41 (1973), 173-178 [Kempisty, str. 173-174, 178; cytuje [K6]]. MR 0318834 (47 \#7380).

\title{
Stefan Kempisty (1892-1940)
}

Izabela Jóźwik, Lech Maligranda and Małgorzata Terepeta

\begin{abstract}
Stefan Jan Kempisty was a Polish mathematician, working in the theory of real functions, set theory, integrals, interval functions and the thory of surface area. In 1919 he defended his Ph.D. thesis On semi-continuous functions at the Jagiellonian University in Kraków under supervision of Kazimierz Żorawski. In December 1924 he did habilitation at the Warsaw University and from 1920 to 1939 he worked at the Stefan Batory University in Vilnius. He published over forty scientific papers, three textbooks and one monograph. He represented in his papers and on seminars the Warsaw school. Kempist's name in mathematics appears in connection with the definition of quasicontinuous functions, different kind of continuity of functions of several variables, the classification of Baire, Young and Sierpiński functions, interval functions and Denjoy and Burkill integrals.
\end{abstract}

We took interest in Kempisty because of his academic achievements, some unexplained personal information, and his 125th birthday in 2017. So we present his biography, participation in conferences, the silhouette his wife Eugenia and daughter Maria, and his scientific achievements. All information about it comes from the following main sources: 
[Kf1]-[Kf4], [Kf8], [Kf9], [Kf12]-[Kf14], [Kf16], [Kf19], [Kf20], [Kf22][Kf25].

2010 Mathematics Subject Classification: 01A60, 01A70, 26A21, 26A75, 28B15, 28B20.

Key words and phrases: 20th century mathematics and mathematicians in Europe, bibliographic studies, Stefan Kempisty, Kempisty's integral, quasi-continuous functions, interval functions, surface area.

IZABELA JóźWIK

POLITECHNIKA ŁÓDZKa

Centrum Nauczania Matematyki i Fizyki

AL. Politechniki 11

90-924 ŁóDź

E-mail: ijozwik@p.lodz.pl

Lech Maligranda

LuleA University of Technology

Department of Engineering Sciences and Mathematics

SE-971 87 LULEÅ, SWEdEN

E-mail: lech.maligranda@ltu.se

MaŁgorzata Terepeta

POLITECHNIKa ŁóDZKa

Centrum Nauczania Matematyki i Fizyki

AL. Politechniki 11

90-924 ŁÓDŹ

E-mail: terepeta@p.lodz.pl

Communicated by: Danuta Ciesielska i Roman Duda

(Zgłoszona: 19 lipca 2016; Wersja końcowa: 21 stycznia 2018) 